\title{
WP 3307
}

PIERRE L. SIKLOS

Wilfrid Laurier University, Viessmann Research Centre, Canada and The Rimini Centre for Economic Analysis, Italy

\section{The Fed's Reaction to the Stock Market During the Great Depression: Fact or Artefact?}

Copyright belongs to the author. Small sections of the text, not exceeding three paragraphs, can be used provided proper acknowledgement is given.

The Rimini Centre for Economic Analysis (RCEA) was established in March 2007. RCEA is a private, non-profit organization dedicated to independent research in Applied and Theoretical Economics and related fields. RCEA organizes seminars and workshops, sponsors a general interest journal The Review of Economic Analysis, and organizes a biennial conference: Small Open Economies in the Globalized World (SOEGW). Scientific work contributed by the RCEA Scholars is published in the RCEA Working Papers series.

The views expressed in this paper are those of the authors. No responsibility for them should be attributed to the Rimini Centre for Economic Analysis. 


\title{
The Fed's Reaction to the Stock Market During the Great Depression: Fact or Artefact?
}

\author{
Pierre L. Siklos \\ Department of Economics \\ Wilfrid Laurier University \\ Waterloo, Canada
}

[This Draft: August 2007]

\begin{abstract}
* Earlier versions were presented at the ASSA Cliometrics Society Meetings, Philadelphia, York University, the Bank for International Settlements, the Norwegian School of Economics, the Norges Bank, and the Hong Kong Monetary Authority. The advice and comments by Robert Barsky, Michael Bordo, Andy Filardo, Bob Hetzel, Lars Jonung, Goetz von Peter, Dagfinn Rime, Hugh Rockoff, Eugene White, various seminar participants, three anonymous referees and the Editor, are gratefully acknowledged. Bob Rasche kindly provided vintages of industrial production for 1927-35. Results not shown are relegated to a separate appendix.
\end{abstract}




\title{
The Fed's Reaction to the Stock Market During the Great Depression: Fact or Artefact?
}

\begin{abstract}
$\underline{\text { Abstract }}$
A notable feature of the 1920 s and 1930s is the volatility in several key macroeconomic aggregates, and this feature used to econometrically identify the reaction of the Fed to stock market developments. The volatility of economic activity may have contributed to deepening the divisions among policy-makers about how the Fed ought to respond to stock price developments. Relying on the technique of Rigobon (2003), volatility is used as an instrument to estimate the Fed's response to the stock market. Other identification assumptions based on structural VARs produce compatible results. Fed behavior appeared to have changed following the stock market crash of 1929. Consistent with the Riefler-Burgess doctrine, interest rates and stock returns are negatively related. I conclude that, prior to the stock market crash of 1929, a form of benign neglect explains Fed behavior. Thereafter, the Fed reacts only slightly more aggressively to stock market developments.
\end{abstract}

Pierre L. Siklos

Department of Economics

Wilfrid Laurier University

Email: psiklos@wlu.ca

Home page: www.wlu.ca/sbe/psiklos

JEL Codes : E52, E58, C32, C52 


\section{Introduction}

An enormous literature explores the events surrounding the 1929 stock market crash in the United States. The present paper provides new evidence about the role that stock prices played in influencing the conduct of monetary policy at the Fed over the period from 1920 to 1938. I find that Fed policy amounted to fueling the rise in stock market prices prior to the fall of 1929. This result may be explained by disagreement amongst policy makers over how to respond to asset price developments before the stock market crash, reflecting divisions over the degree of activism deemed adequate in the conduct of monetary policy (e.g., see Friedman and Schwartz 1963, pp. 254-66). There is also some evidence that Fed responses may have fueled the stock price increase that resulted in the Great Crash. In contrast, the Fed appears to have responded more appropriately to stock market developments, especially during the 1930s by increasing interest rates when stock prices were rising. Broadly speaking, the contemporaneous correlation between a key interest rate and stock returns is negative before the crash of 1929 but turns positive following that pivotal event. It is argued that the volatility of selected macroeconomic indicators is a critical ingredient to understanding this period of US economic history.

Meltzer (2003) is perhaps the latest to suggest that Federal Reserve policy during the 1920s and 1930s was significantly affected by stock market developments. He downplays other interpretations of the Great Depression, such as the debt-deflation view of Bernanke (1983) and Fisher (1933), the impact of Benjamin Strong's death in 1928 (Friedman and Schwarz 1963), the Fed's poor understanding of the role of monetary policy (Wicker 1966), and Eichengreen's (1992a) emphasis on the breakdown of international cooperation under the constraints imposed by the Gold Standard. Meltzer, however, is neutral on the question of whether the Fed actively responded to the stock market. Romer $(1990,1992)$ takes the view that links exist between stock market performance and Fed decisions during the 1920s, while Rappoport and White (1994) conclude that there were signs, especially in financial markets, that the 1929 stock market collapse may have been anticipated at least a year in advance. An unresolved issue is whether the era considered in this paper should be treated as a single "regime" instead of one subject to a break around 1928 or 1929. For example, there is some evidence to suggest that the conduct of 
monetary policy may not have changed drastically from the early 1920s through most of the 1930s (e.g., Wheelock 1991, Meltzer 2003). ${ }^{1}$

This paper provides new evidence to identify, econometrically, the contemporaneous relationship between stock market returns and interest rates. One approach (e.g., Orphanides 2003; Wheelock 1991) is to estimate a Taylor type rule. While such a relationship would not have been known at the time, the notion that the Fed ought to actively conduct policy so as to maintain some form of price stability was, in fact, widely discussed both inside and outside the Fed during the 1920s (e.g., Friedman and Schwartz 1963, pp. 254-66, Eichengreen 1992a, Meltzer 2003 (pp. 181-92), Hetzel 2007 (Chapter 3)). It is important to emphasize that estimation of a reaction function for this period in U.S. economic history should be viewed purely as a heuristic device. Such an approach helps underscore the notion that the Fed was concerned with macroeconomic events, not in a mechanical fashion, of course, but in a broad sense. Several authors (e.g., Wheelock 1991, Orphanides 2003, Bordo, Helbling and James 2006) have relied on the estimation of reaction functions to describe the conduct of monetary policy during selected historical epsiodes. Moreover, it is also correct to state that, over the sample considered in this paper, a short-term interest rate served as a policy instrument. Therefore, it is convenient to examine the hypothesis addressed in this paper through the device of a Taylor rule (also see Wheelock 2000, Hetzel 2007 (Chapter 3)).

Other than Wheelock (1991, Chapter 2) there has, to my knowledge, been no attempt to estimate a "reaction function" for the Federal Reserve over this period, or to econometrically test whether stock market or credit developments influenced Fed behavior. As we shall see, the results of this approach illuminate Fed actions particularly when real time data are employed, or if stock market developments are permitted to play an (indirect) role in the reaction function specification. Because estimates from standard policy rules do not entirely satisfactorily measure the reaction of the Fed to stock market developments, I next consider whether stock market volatility can be used serves as an instrument in a statistical sense. This technique is employed in the econometric identification of the Fed's reaction to the stock market, based on the

\footnotetext{
${ }^{1}$ Many authors have identified "breaks" arising from the time series properties of the data (e.g., Perron 1989), significant technological shocks (e.g., Field 1993, Francis and Ramey 2005), errors or changes in the conduct of monetary policy (e.g., Bordo, Choudhri, and Schwartz 2002), or the strains imposed by adherence to a particular economic ideology (e.g., Eichengreen 1992a). Hofman and Rasche (1989), in a study of the demand for monthly M1 (and other monetary aggregates) before World War II conclude that the standard relationship is stable. White (2006) surveys booms and busts in U.S. stock markets during the $20^{\text {th }}$ Century.
} 
methodology of Rigobon (2003). Finally, estimates from a structural VAR are also presented, and these are found to complement the results from the identification through heteroskedasticity approach. Since all three econometric approaches yield findings that support the hypothesis of this paper, there are good econometric grounds to conclude not only that the Fed reacted to stock market developments during the period considered but that the nature of the response changed after the stock market crash of 1929.

To highlight the potential role played by volatility in the analysis to follow, consider Figure 1. Figure 1A plots industrial production growth for the period 1920-1938 together with data for the sample 1985-2003 to provide some perspective. ${ }^{2}$ Figure 1B repeats the same exercise for stock prices. The contrast between the two eras is striking. ${ }^{3}$ More importantly perhaps, for the 1920-1938 period, there are periods of calm followed by years when volatility is large. It is the volatility of key macroeconomic series that points to the technique developed by Rigobon (2003) as a useful means of econometrically identifying the Fed's reaction to the stock market.

An overriding concern among Fed officials during the 1920s was the behavior of asset prices, especially stock prices (Friedman and Schwartz 1963 (pp. 254-67), Hetzel 2007 (Chapter 3)). Some believed that speculation in asset markets presaged an imminent recession. Adherents to a version of the real bills doctrine, called the Riefler-Burgess doctrine (e.g., see Meltzer 2003, p. 161-65), saw no contradiction in maintaining lower interest rates while simultaneously relying on moral suasion, or other instruments at the Fed's disposal, to extinguish feverish stock market speculation. Indeed, it was not until August 1929 that Harrison's point of view succeeded in convincing his fellow governors to raise the Fed's discount rate by a full percentage point (inter alia, Meltzer 2003, Hetzel 2007).

Also germane to the approach adopted in this paper is Bordo and Jeanne (2004), who examine sharp historical asset price reversals in several countries and conclude that a "proactive" policy vis-à-vis asset booms and busts might yield better economic outcomes. As noted above, not all observers agree with this position (e.g., Bernanke 2002, Greenspan 2005).

\footnotetext{
${ }^{2}$ Clearly, the series considered are not identically defined across these samples. Nevertheless, it is difficult to believe that measurement errors or definitional changes can account for most of the large discrepancies in the volatility of these series.

${ }^{3}$ The most recent period covered in Figure 1 essentially overlaps with the Greenspan era. Greenspan (2005) attributes economic developments during his time in office to a combination of economic stability and productivity improvements that "...have propelled asset prices higher." (op.cit., page 3) The latter development was a feature of the economic landscape during the 1920s while the former was not, as is clear from Figure 1.
} 
Moreover, their identification of booms and busts in asset prices is based on the deviation in a moving average relative to a long-run historical average. While this is a plausible, albeit somewhat ad hoc, approach, Figure 1 (also see below) makes the point that volatility may also have played a central role in explaining the Fed's reaction to the stock market boom of 19281929.

The rest of the paper is organized as follows. The next section outlines potential avenues through which the discount rate and the stock market were believed to have been linked. Next, I discuss some data related issues, and provide some suggestive evidence based on Taylor rule estimation using final revised and real time data. Rigobon's (2003) technique of identification through heteroskedasticity is described next, followed by the empirical estimates based on this approach. Additional evidence relying on structural VARs is also reported. The paper concludes with a discussion of the main findings and some of the limitations of the study.

\section{The Monetary Policy - Stock Market Link}

\subsection{The Fed and the Stock Market}

Meltzer's (2003) magisterial account of the history of the Federal Reserve (Fed) during its first decades emphasizes that the Riefler-Burgess doctrine “... played a major role in the 1920s and beyond" (op. cit., p. 138). The doctrine holds that member bank borrowings would be linked to a rise or a fall in the discount rate, replacing the gold reserve ratio as the indicator to which the Fed would respond. A rise in the discount rate was meant to signal a reduction in member bank borrowings. Hence, the level of borrowing serves as an indicator of monetary ease or tightness. However, if banks borrow to expand their asset holdings then monetary ease would take place in a boom while a recession would be associated with monetary restraint. Indeed, Wheelock (1991, p. 48) points out how the misleading signals given by the discount rate led to greater economic instability. Benjamin Strong is said to have suggested that the Fed may have acted when the spread between the discount rate and market rates was "...deemed too far out of line..." (Wheelock 1991, p. 31). ${ }^{4}$

\footnotetext{
${ }^{4}$ It is unclear how large the spread was thought to be necessary to prompt the Fed to react. A plot of the difference between the New York discount rate and the commercial paper rate (not shown) suggests asymmetry in the spread. A threshold model of the spread, estimated using the asymmetric unit root test developed by Enders and Granger (1998), confirms that there is a preponderance of negative values (i.e., the spread is below the threshold) and this may suggest that Fed policy can be interpreted as being consistently too easy until about 1932 . The obligatory caveat about the relatively low power of unit root tests should be mentioned.
} 
Of particular concern to many Fed officials at the time were how loans were being used. Since the real bills doctrine view of monetary policy prevailed many, including Chairman Adolph Miller, believed that loans used to fuel stock purchases were unproductive and, therefore, ought to be discouraged. Others also shared the view that borrowings contributed to influencing share price movements (e.g., Reed 1930) and that the source of the problem was the discount rate policy of the Fed. Dominguez, Fair, and Shapiro (1988), report that the Harvard Economic Service and Irving Fisher were unable to forecast the severity of the Great Depression of the 1930s. ${ }^{5}$ Nevertheless, both forecasting groups were interested in the links between interest rates (viz., the commercial paper rate) and equity returns (op.cit., p. 598). Of course, not everyone inside or outside the Fed accepted the need to use discount rate policy to offset real or perceived stock market excesses. Benjamin Strong, for one, was skeptical of the argument noting that higher interest rates will also affect businesses and individuals not involved in stock market related transactions (Meltzer 2003, p. 225). Harris (1933, p. 186 ff) argues that the Fed focused wrongly on reserve bank credit outstanding instead of member bank balances, that is, roughly what would today be referred to as the monetary base. Friedman and Schwartz (1963, pp. 25466) argue that the Fed effectively resisted using 'direct pressure' on speculative loans via changes in the rediscount rate until 1929. Indeed, Fed actions prior to that time may well have fueled the stock market boom until the crash of 1929.

The central role played by monetary considerations in these discussions reflects the fact that the principal goal of the young Federal Reserve System was to maintain steady credit conditions (also see Humphrey 2001). Currie (1934) is a succinct summary of this view, as is Harris' (1933) who, like Meltzer (2003), underscores the ambivalence, if not hesitation inside the Fed, about whether stock market activity ought to elicit any monetary policy response. Currie (1934) cites Keynes (1950) who approves of policy-makers displaying a concern for stock market developments. "Thus during the Wall Street boom of 1929 attention was rightly paid to increases and decreases in the volume of loans made by "broker houses ..." (op. cit., p. 251). The fact that some, but not all, policy-makers were concerned about the impact of a stock market bust

\footnotetext{
${ }^{5}$ McGrattan and Prescott (2004) argue that Fisher believed the stock market to be undervalued on the eve of the stock market crash.
} 
on the creditworthiness of some borrowers is not surprising since the 1920s represented a period of rapid growth in nominal debt (Fackler and Parker 2005). ${ }^{6}$

Attempting to decipher the motivations of policy-makers is further complicated by an impression that individual policymaker's views were rather changeable depending on the circumstances. Therefore, over the period studied here, the monetary policy regime may have changed. ${ }^{7}$ Friedman and Schwartz (1963) argue that Benjamin Strong's death brought about at least one regime change. Eichengreen and Mitchener (2004) also highlight what they believe is instability in the conduct of monetary policy. Others, of course, prefer to emphasize changes in the perception of policy-makers about how to ensure price stability or, rather, errors of judgment about the source and influence of financial market developments such as those taking place in the stock market (e.g., see Wicker 1965, Romer 1992, Calomiris and Wheelock 1998).

There was also an element of hubris among the governors of the Fed could also be detected. After all, for a good part of the 1920s, and especially in 1923, the Fed delivered price stability and had successfully used discount rate policy to achieve that outcome when the prospect of an overheating economy was defused by what today would be called a pre-emptive strike. Moreover, there were concerns expressed over the volatility of credit movements and, indeed, whether these could somehow contribute to errors in judgment over the proper course for monetary policy. For example, Reed (1930, p. 198) writes that “... mistakes have usually been later admitted whenever the aggregate credit supply of the country has been permitted to undergo pronounced fluctuations for any extended period of time." However, there was no recognition that deflation and real interest rate behavior were connected. Instead, the focus was almost exclusively on the "speculative excesses" of credit markets and the desirability to stamp these out. $^{8}$

\footnotetext{
${ }^{6}$ Not all sectors were equally affected. See Olney (1999) and Fackler and Parker (2005, n. 7) for additional references.

${ }^{7}$ Moreover, as one referee correctly points out, until 1933, regional federal reserve banks could, and occasionally did, individually set discount rates. However, by 1923, attempts to centralize the conduct of monetary policy were well underway and, though not always successful, policy-makers did begin to recognize that the System was playing an increasingly important role in determining national credit and monetary conditions (e.g., Meltzer 2003, pp. 15343).

${ }^{8}$ Moral suasion, and margin requirements, are frequently mentioned as "instruments" to achieve "quantitative" objectives" using "qualitative" tools. Humphrey (2001) uses this nomenclature to explain Fed behavior during the 1920s and 1930s. However, there is little hard evidence as to how these might have actually influenced speculative activity. On the importance of margin requirements in the debt-deflation literature, see von Peter (2005).
} 
Wheelock (1991, Chapter 2), using the first difference of the discount rate, estimates purely backward-looking reduced form reaction functions. He reports a positive relationship between the lagged stock return and the current change in the discount rate. However, Wheelock's specification is unable to identify the Fed's reaction to stock market developments since the variables in question are simultaneously determined.

It is clear from the foregoing discussion that asset price developments played an important role in policy deliberations throughout the 1920s and 1930s but it is unclear to what extent the Fed reacted to them. ${ }^{9}$ By the 1930s hints emerge of a possible change in Fed policy. However, the real bills doctrine was not entirely expunged from Fed thinking. While it “... no longer had the force of law behind it" (Meltzer 2003, p. 485), the ... "Riefler-Burgess doctrine continued as a general guide to policy actions ..." (op. cit., p. 413). The lessons of the 1920s had still not been fully learned. ${ }^{10}$

Finally, I would be remiss for failing to touch upon the evolution of decision-making at the Fed, and its impact on the conduct of monetary policy. Wheelock (2000) reviews all the relevant issues and argues, in contrast to Eichengreen (1992b) and Friedman and Schwartz (1963), that the decentralized decision-making structure of the Fed prior to the implementation of the Banking Acts of 1933 and 1935 was not the proximate cause for the monetary policies that ultimaltely gave rise to the Great Depression beginning in $1929 .{ }^{11}$ As Wheelock (2000) goes on to argue, reserve banks could not effectively set their discount rate oblivious to levels set by other regional Federal Reserve banks. As a result, there was not total uniformity in discount rates across regions. However, it is not inappropriate to rely on New York rates as representative of

\footnotetext{
${ }^{9}$ Concerns over stock market developments do not imply that the Fed had some numerical target for stock prices. I could not find any references to specific stock price index levels Fed officials might have had in mind when deliberating or discussing the stance of monetary policy. In written correspondence, Michael Bordo, Bob Hetzel, Hugh Rockoff and Eugene White also confirm the absence of any formal stock price or stock return target. ${ }^{10}$ Mehrling (2002) also examines the varieties of conflicting views about the role of the Fed during the 1920s and 1930s. Unlike modern-day monetary policy implementation, students of U.S. economic history of the 1920s and 1930s do not have at their disposal mathematical expressions of the "models" Fed policy makers might have in mind when they outlined their views about the impact of stock market conditions on the economy. Nevertheless, it is still the case today that monetary policy decisions are based on more than just a suite of models. As noted in the introduction, the interpretation of monetary policy actions is based on a heuristic depiction of the presumed link between macroeconomic and financial variables that appears in discussions of monetary policy by Fed officials throughout the 1920s and 1930s.

${ }^{11}$ Even Eichengreen (1992b) admits that not only was there ambiguity in the 1913 Federal Reserve Act statement: "Every Federal reserve bank shall have the power...to establish from time to time, subject to review and determination by the federal Reserve Board, ..." (emphasis added) but that there were strong pressures favoring centralization by the mid 1920s.
} 
interest rate levels across the whole system, and this is the position adopted in the empirical analysis that follows (also see Eichengreen 1992b).

\subsection{Monetary Policy and the Stock Market in Theory}

A popular view of the determination of stock prices is that they reflect expectations of future cash flows or changes in the discount factor. Another important strand of the literature views stocks as a hedge against inflation and, therefore, as an indicator of future economic activity. On the one hand, there is empirical evidence that links the stance of monetary policy, notably monetary expansions, with stock market performance (e.g., Thorbecke 1997). On the other, more recent evidence for the G7 countries suggests that the forecasting ability of asset prices is rather poor (Stock and Watson 2003).

An important contribution by Allen and Gale (2000) posits that because stocks and real estate are often purchased with borrowed funds there is an incentive for borrowers to shift risk to lenders who may not be able to observe the underlying risks of the investments made by borrowers. This produces an agency problem. Consequently, as bank credit expands, asset prices react more strongly than in the discounted expected payoff scenario. Hence, asset price volatility is an indicator of the consequences of excessively rapid bank credit expansion. It is this result that motivates adopting the identification through heteroskedasticity methodology due to Rigobon (2003) to estimate the contemporaneous relationship between stock returns and interest rates. When shocks produce greater volatility in the stock market, the covariance between interest rates and stock returns is assumed to rise and this implies a positive link between these two variables.

Rigobon and Sack (2003) find that the contemporaneous relationship between interest rates and stock market returns is positive for the Fed during the 1980s and 1990s. Bjørnland and Leitemo (2005), who estimate a structural VAR over roughly the same period in U.S. economic history, also report results compatible with the ones in Rigobon and Sack (2003). The possible connection between interest rates and stock returns, in particular, has also spawned a separate literature that asks whether or not it is appropriate for a central bank to target asset prices (e.g., Filardo 2001). That literature, however, is divided about the practicability of such a policy (e.g., see Bordo and Jeanne (2004), and references therein). Rigobon and Sack (2003) report that the Fed reacts to stock returns whereas it might be argued that central banks care more about stock 
prices that deviate significantly (in an economic sense) from some underlying trend driven by fundamental economic factors (e.g., see Bohl, Siklos, and Werner 2007).

\section{Data and Stylized Facts}

Monthly data are used in the results reported below. Although the full sample considered consists of data for the period 1920-1938, data limitations mean that some specifications were estimated over slightly shorter samples. Monetary data are from the Board of Governors (1943), stock market index data were obtained from Global Financial Data (http://www.globfindata.com), with additional macroeconomic data from the NBER's Macrohistory data base (http://www.nber.org/databases/macrohistory/contents/), and the Federal Reserve Bank of St. Louis FRED2, ALFRED and FRASER databases. Real time data, consisting of vintage data for industrial production, were collected from the Fed Bulletin. ${ }^{12}$

Figure 2A plots a variety of monthly short-term interest rates. The empirical evidence reported below relies on the New York commercial paper rate series (solid line) which appears broadly representative of the movement of short-term interest rates more generally. Also shown are the business cycles peaks and troughs as dated by the NBER. In the space of approximately 19 years there were five recorded recessions (peak to trough periods). Figure 2B plots two indicators of stock returns, based on the close of the Standard and Poor's index. The relatively noisy line is 100 times the monthly log change of the index while the relatively smoother line is the annual rate of change in same index. The latter highlights, most clearly, the 1929 stock market crash. Monthly returns also emphasize the changing volatility of stock returns over time and, once again, the period of the 1929 stock market collapse is clearly visible.

Figure 3 plots rolling standard deviations of S\&P monthly returns and the commercial paper rate (top portion), while the simple rolling correlation between these same series is plotted separately (bottom portion). Rolling correlations tend to be negative more often prior to 1929 than in the 1930-38 period. Rising or falling volatility in interest rates is accompanied by similar changes in the standard deviation of S\&P returns. In general, interest rates are more volatile in the early 1920s, and then again in the late 1920s and early 1930s, at least based on monthly data. Volatility is relatively high for stock prices around the time of the stock market crash. An obvious alternative to the rolling estimates is to rely on a conditional volatility model, such as a

\footnotetext{
${ }^{12}$ Since this paper was first written, all vintages of industrial production since January 26, 1927 are now available from the Federal Reserve of St. Louis' ALFRED data base (ALFRED, ArchivaL Federal Reserve Economic Data: http://alfred.stlouis.org).
} 
$\operatorname{GARCH}(1,1)$, to identify the volatility regime (see below). Another strategy consists in estimating a Markov switching model. Using the procedures outlined in Hamilton (1994, chapter 22), I also estimate the (smoothed) probability of being in a high volatility regime based on the behavior of several key time series. ${ }^{13}$ They are, at the monthly frequency: inflation, money supply growth, the growth in industrial production, U.S. gold stocks, borrowing at the Federal Reserve, and the (log) dividend-price ratio. ${ }^{14}$ At the weekly frequency, volatility regimes are identified from the residuals of a VAR to be described below. In the case of inflation, at least three high volatility regimes are identified: one begins at the end of the 1920s, followed by another one shortly after 1932. A third high volatility regime begins around the mid-1930s. Money growth produces comparable results. For industrial production, as well as the other series considered, low volatility regimes are the exception with one occurring around 1933 and another in 1934-1935. It is likely that the probability estimates for industrial production are sensitive to the sheer size of the drop in output during the Great Depression. (see Figure 1). Turning to fed borrowings, whose importance is underscored by Wheelock (1991, 47ff), a brief low volatility regime is apparent in 1931 then again in 1933, 1934-35, and 1938. All of these estimates suggest several alternative dating schemes are candidates for high volatility regimes. Therefore, these results provide us with the opportunity to assess the robustness of our findings linking stock returns to interest rate movements to be presented in subsequent sections.

\section{Policy Rules for the 1920s and 1930s}

As is now well-known, policy evaluations based on estimates using final revised data can be misleading. Orphanides (2001) shows, for the U.S. for the period covering the 1980s to early 1990s, that policy prescriptions based on real-time data yield vastly different coefficient estimates from ones obtained using final revised data. Figure 4 plots revisions to monthly industrial production based on four vintages of data. They are: September 1927, September 1929, March 1933, and September 1935. Data using other vintages yield comparable results. However, these four were chosen because they represent important milestones in the sample considered (Meltzer 2003, p. 174ff). In May 1927 the Fed began open market operations, while November

\footnotetext{
${ }^{13}$ Maximum likelihood parameter estimates are relegated to an appendix (not shown).

${ }^{14}$ Borrowings at Federal Reserve banks is from Table 50 (Board of Governors 1943), industrial production is series M16002Q from the NBER historical data set (www.nber.org), gold reserves is series M14131G, also from the NBER historical data collection. Dividend price ratio data are taken from Robert Shiller's website (http://aida.econ.yale.edu/ shiller/).
} 
1927 is when the NBER identifies the trough of a recession. In addition, Meltzer (2003) argues that discussions inside the Fed about stock market speculation took on a bigger role by mid1927. September 1929 is likely the last time that Fed officials would have seen industrial production data prior to the stock market crash. February 1933 is the vintage just prior to Roosevelt's inauguration, while September 1937 is the last available vintage used in this study. ${ }^{15}$ Figure 4 plots the percent differences in the level of industrial production between the 1927 or 1929 vintages relative to the 1933 or 1935 vintages. Comparing the 1927 and 1929 vintages we find that most revisions were positive, an indication that industrial production was seen as having been higher than the actual data available in 1927 would have suggested. Revisions are consistently in the 1-2\% range and significantly different from zero. By 1933 or 1935, revisions are not statistically different from zero, and the sample variance is not significantly different from one. The last result does not hold, however, when the 1927 and 1935 vintages are compared. A comparison of the September 1929 vintage with subsequent vintages also yields a mean zero revision but the variance is significantly greater than one. Indeed, what is striking about the 1927 and 1929 vintages, relative to the 1933 or 1935 ones, are the relatively large errors in the 1921-22 period with many revisions in the order of 4 to $8 \%$. It appears that earlier vintages of industrial production tended to be overly optimistic about output in the US economy while some revisions to 1921 and 1922 data suggest that the recovery was stronger than originally perceived. It is worthwhile recalling that the Fed's thinking and concern over stock market developments began to change around 1928, as noted by Friedman and Schwartz (1963) and Meltzer (2003), among others. It is clear, therefore, that real time data offer some insights into what may have prompted the Fed to rethink its stance on monetary policy. Finally, someone in 1933 looking back on economic performance in September 1929 would have revised downward several monthly estimates of industrial production from 1925-1928.

Orphanides (2003) argues that the eponymous Taylor rule can serve as a device to aid in the understanding of the historical monetary policy performance of the Fed during the 1920s and 1930s. However, he does not formally present estimates of a Fed reaction function. Hetzel (2007, 2008) also argues that it is useful to interpret the Fed's monetary policy over the course of its history as akin to the application of a succession of rules that may be modified when events

\footnotetext{
${ }^{15}$ I also tried to construct a real-time data set for wholesale and consumer prices based on the Survey of Current Business but there were too few observations for inclusion in the subsequent analysis.
} 
dictate the need to make adjustments. In what follows I estimate reaction functions of the form suggested by Giannoni and Woodford (2003; also see Woodford 2003, p. 584ff), and Orphanides (2003). The form of the estimated reaction functions are thought to be the most robust to changes in underlying economic conditions. Giannoni and Woodford (2003) specify a Taylor rule of the form

$i_{t}=i^{*}+\rho_{1} i_{t-1}+\rho_{2} \Delta i_{t-1}+\phi_{\pi} \pi_{t}+\phi_{\Delta \tilde{y}} \Delta \tilde{y}_{t}+\varepsilon_{t}$

where lagged changes in interest rates $\left(\Delta \mathrm{i}_{\mathrm{t}-1}\right)$ also determines $i_{\mathrm{t}}{ }^{16}$ The change in the output gap reflects the need to account for large measurement errors in this variable. Commitment to such a rule is shown to imply a determinate equilibrium from a timeless perspective and, as such, is optimal, as well as satisfying the Taylor principle. That fact that equation (1) is based on the current projection of inflation and the output gap also seems consistent with the manner in which monetary policy would have been carried out in the period considered in this study.

Orphanides (2003) recommends a rule that contains both forward and backward-looking elements, as well as the level of the output gap, and is written

$i_{t}=i^{*}+\rho_{1} i_{t-1}+\phi_{\pi} \pi_{t+3}+\phi_{\Delta \tilde{y}} \Delta \tilde{y}_{t+3}+\phi_{\hat{y}} \tilde{y}_{t-1}+\varepsilon_{t}^{\prime}$

where $\pi_{t+3}$ and $\left(\Delta \hat{y}_{t+3}\right)$ are the three months ahead conditional expectations of inflation and the change in the output gap. Orphanides (2003, p. 1007) shows how this specification nests various forms of the Taylor rule that have appeared in the literature.

Expressions such as (1) are often estimated via least squares. In contrast, equations such as (2) are usually estimated via Generalized Method of Moments (GMM) since the forwardlooking terms are endogenous. Estimated coefficients are shown in Tables 1 and 2. Full sample estimates based on final revised data produce an estimated natural real rate of interest of $1.65 \%$ (col. 1) but this coefficient is not statistically significant at conventional significance levels. The estimate of the steady-state impact of inflation on the nominal interest rate is below one, the threshold suggested by the Taylor principle, but one cannot reject the null that $\phi_{\pi}=1$ using a Wald test. ${ }^{17}$ Notice, however, that the sign on $\phi_{\Delta \tilde{y}}$ is incorrect, indicating that a larger positive deviation in the output gap results in a reduction in the interest rate. Given that real time date

\footnotetext{
${ }^{16}$ It should be noted that Giannoni and Woodford (2003) also consider other rules that incorporate more forwardlooking behavior but argue in favor of a rule such as (1).

${ }^{17}$ The steady state parameters are obtained by dividing the estimated coefficients by $\left(1-\rho_{1}\right)$.
} 
(see below) reveals that the actual fall in output was larger than expected, this finding may not be surprising. There is also evidence that the residuals are severely non-normal. It is, of course, possible that the coefficients are unstable over the period considered. Hence, some sub-sample estimation is clearly in order.

Hansen's (1997) test for a break in a linear regression based on a threshold variable (here the lagged interest rate) suggests a break in November 1929. This appears to be a sensible choice for a break given that the stock market crash took place at the end of October. Other breaks are possible, of course, but estimating (1) and (2), for shorter samples, jeopardize the economic significance that one can attach to any of the coefficients. ${ }^{18}$ The pre-crash sample reveals an equilibrium real interest rate of $4.48 \%$ (col. 2) while the same estimate for the post-crash era is far lower at $1.26 \%$ (col. 7), though still significantly different from zero. The Fed seems to have behaved roughly as the Taylor principle would predict, at least in the pre-crash sample.

The picture is quite different once we consider real-time data (cols 3 to 6). Based on the September 1927 vintage, Fed policy appears to be loose since no statistically significant response to inflation is detected and the equilibrium real interest rate not statistically different from zero. Unlike estimates based on final revised estimates, however, there is a significant and positive reaction to changes in the output gap. When the September 1935 vintage of data is considered, we now find that Fed monetary policy is restrictive since the estimated equilibrium real interest rate is found to be $4.71 \%$, and there is a greater than unit response in the nominal interest rate from a rise in inflation. While such estimates are instructive, they do not provide any indication about whether the Fed's response was influenced by stock market developments. ${ }^{19}$

Estimates of forward-looking policy rules appear in Table 2. The reaction to inflation shocks based on equation (2), though positive, is insignificant in both samples. Interestingly, there is not much evidence that the degree of interest rate smoothing, high throughout, changed over time with persistence (i.e., $\rho_{1}$ ). There remains significant serial correlation in the squared residuals, however, only in the pre-crash sample.

\footnotetext{
${ }^{18}$ Sensitivity tests were carried out assuming breaks in the neighbourhood of November 1929 but the conclusions discussed below are unchanged. I also estimated a version where allowance is made for individual Board Directors throughout the sample to have a separate influence on the course of interest rate developments (i.e., Harding, Crissinger, Young, Meyer, Black and Eccles administrations) but the relevant dummy variables were all statistically insignificant ( $\mathrm{p}$-values in excess of 0.10).

${ }^{19}$ In principle, one could also add a stock market return variable to equations (1) and (2) but this creates additional econometric problems. For example, see Fuhrer and Tootell (2004), and references therein. I explicitly deal with this issue in the following section.
} 
An important element in GMM estimation, often ignored, is the choice of instruments. If these are weak the resulting biases can lead to misleading inferences (see Hall 2005). Accordingly, Table 2 also presents tests of instrument relevance. These measures indicate the extent to which the chosen instrument set is correlated with the endogenous variables in the policy rule (while being orthogonal to the residuals). The tests reveal that lagged money growth and stock returns are the most statistically relevant instruments, as demonstrated by the partial $\mathrm{R}^{2}$ and F-tests also shown in Table 2 (SET 2 and SET 3, respectively), whereas a standard instrument set that relies only on lags of the right hand side variables (SET 1), typically the strategy followed by most researchers, is less adequate. This is especially true for the sample that spans the post 1929 stock market crash. ${ }^{20}$

What are we to make of these results? First, the Fed clearly under reacted to inflation or deflation. Second, when stock returns are used as instruments the performance of a Taylor rule improves, especially before 1929.

\section{Identifying Policy Reactions to Stock Prices}

\subsection{Identification Through Heteroskedasticity}

The motivation behind Rigobon and Sack's (2003) identification technique (also see Rigobon 2003) is similar to the one used to solve the identification problem in the standard example of supply and demand curves. It requires identification of volatility regimes in order to estimate the slope parameters of interest, namely how stock price changes affect interest rate movements.

To investigate the relationship between the Fed's monetary policy and the stock market, I adapt version of the dynamic structural equations specified by Rigobon and Sack (2003) written as:

$$
\begin{aligned}
& i_{t}=\beta s_{t}+\theta x_{t}+\gamma z_{t}+\varepsilon_{t} \\
& s_{t}=\alpha i_{t}+\phi x_{t}+z_{t}+\eta_{t},
\end{aligned}
$$

where $i_{t}$ denotes the short-term interest rate and $s_{t}$ represents stock returns or some other proxy for stock market performance. The parameter we are interested in is $\beta$ in equation (3). The vector $x_{t}$ contains lags of $i_{t}$ and $s_{t}$, as well as inflation and the output gap, while $z_{t}$ captures

\footnotetext{
${ }^{20}$ While I am unable to produce forward-looking estimates based on real-time data, it is instructive to note that some of the key variables that forecasters at the time relied upon, namely money supply and equity returns (e.g., see Dominguez, Fair and Shapiro 1988), appear to be the most relevant instruments.
} 
other unobservable shocks that may affect stock returns and the interest rate. The inclusion of $z_{t}$ completes the specification of the model and rules out factors that could also explain the covariance between monetary policy actions and the stock return. The coefficient on $z_{t}$ in (4) is normalized to 1 .

Equation (3) is the monetary policy reaction function, and is the focus of this paper, (4) is the stock market reaction function, and the policy shock variable $\varepsilon_{t}$ is orthogonal to the stock market shocks $\eta_{t}$. Note that reaction function (3) can be interpreted as a version of the conventional Taylor rule augmented by the stock returns variable. At the monthly frequency, we write $x_{t}=[\pi, \tilde{y}]^{\prime}$, where $\pi$ represents inflation and $\tilde{y}$ is the output gap.

If the parameter $\alpha$ is different from zero, equation (3) cannot be estimated via OLS since $\beta$ is then a biased estimate of the reaction of the short-term interest rates to stock price changes owing to the simultaneity problem referred to above. Moreover, $z_{t}$ is unobservable which further contributes to a bias in OLS estimates of $\beta$. Instead, an identification strategy is required. While several identification strategies are available, the Rigobon procedure exploits changes in the volatility in the time series of interest to permit estimation of the parameter $\beta$. We begin with a reduced form version of (3) and (4) written as a VAR:

$$
\left(\begin{array}{c}
i_{t} \\
s_{t}
\end{array}\right)=\Phi x_{t}+\left(\begin{array}{c}
v_{t}^{i} \\
v_{t}^{s}
\end{array}\right)
$$

The residuals in reduced form, are:

$$
\begin{aligned}
& v_{t}^{i}=\frac{1}{1-\alpha \beta}\left[(\beta+\gamma) z_{t}+\beta \eta_{t}+\varepsilon_{t}\right] \\
& v_{t}^{s}=\frac{1}{1-\alpha \beta}\left[(1+\alpha \gamma) z_{t}+\eta_{t}+\alpha \varepsilon_{t}\right]
\end{aligned}
$$

and the covariance matrix of the reduced form residuals is:

$$
\Omega=\frac{1}{(1-\alpha \beta)^{2}}\left[\begin{array}{cc}
(\beta+\gamma)^{2} \sigma_{z}^{2}+\beta^{2} \sigma_{\eta}^{2}+\sigma_{\varepsilon}^{2} & (1+\alpha \gamma)(\beta+\gamma) \sigma_{z}^{2}+\beta \sigma_{\eta}^{2}+\alpha \sigma_{\varepsilon}^{2} \\
\cdot & (1+\alpha \gamma)^{2} \sigma_{z}^{2}+\sigma_{\eta}^{2}+\alpha^{2} \sigma_{\varepsilon}^{2}
\end{array}\right] .
$$

The covariance matrix provides only three moments (the variance of $i_{t}$, the variance of $s_{t}$, and the covariance between $i_{t}$ and $s_{t}$ ) but there are three unknown coefficients, namely $\alpha, \beta$ and 
$\gamma$, as well as three unknown variances $\sigma_{z}^{2}, \sigma_{\eta}^{2}$ and $\sigma_{\varepsilon}^{2}$. Instead of imposing zero restrictions on the parameters of (3) and (4), a standard approach to the identification problem (also, see below), an alternative strategy is proposed. If the covariance does not remain constant, a shift to a regime with a different covariance matrix provides three new equations as well three new unknown parameters, namely $\sigma_{z}^{2}, \sigma_{\eta}^{2}$ and $\sigma_{\varepsilon}^{2}$. Consequently, there are now effectively 9 unknowns. If we then impose the restriction that the monetary policy shock, $\sigma_{\eta}^{2}$, is constant we are left with 8 unknowns and 8 parameters and this permits just identification. ${ }^{21}$ Hence, three additional equations are generated when there is a shift in the covariance matrix. Identification in this case requires at a minimum three volatility regimes.

As shown in Rigobon and Sack (2003), and also in Rigobon (2003), the $\beta$ parameter must solve the following system of equations:

$$
\begin{aligned}
& \theta=\left(\Delta \Omega_{21,12}-\beta \Delta \Omega_{21,12}\right) /\left(\Delta \Omega_{21,11}-\beta \Delta \Omega_{21,12}\right), \\
& \theta=\left(\Delta \Omega_{31,12}-\beta \Delta \Omega_{31,22}\right) /\left(\Delta \Omega_{31,11}-\beta \Delta \Omega_{31,12}\right) .
\end{aligned}
$$

This is a system of equations with two unknowns $(\theta, \beta)$ and is, therefore, just identified when there are three volatility regimes. Each additional regime requires another equation of the same type in which case the system becomes over-identified. In this case it is possible to test for the validity of over-identifying restrictions and this allows us to test the stability of the $\beta$ parameter.

The terms in (9) and (10) represent elements that produce changes in the covariance matrices from regime $i=1$ to $i=2,3$. These can be identified with the help of the covariance matrix under each regime $i=1,2,3$ written as:

$$
\Omega_{i}=\frac{1}{(1-\alpha \beta)^{2}}\left[\begin{array}{cc}
(\beta+\gamma)^{2} \sigma_{i, z}^{2}+\beta^{2} \sigma_{i, \eta}^{2}+\sigma_{\varepsilon}^{2} & (1+\alpha \gamma)(\beta+\gamma) \sigma_{i, z}^{2}+\beta \sigma_{i, \eta}^{2}+\alpha \sigma_{\varepsilon}^{2} \\
. & (1+\alpha \gamma)^{2} \sigma_{i, z}^{2}+\sigma_{i, \eta}^{2}+\alpha^{2} \sigma_{\varepsilon}^{2}
\end{array}\right] .
$$

Moreover, defining the change of the covariance matrix from regime $i=1$ to regime $i=2$ as $\Delta \Omega_{21}=\Omega_{2}-\Omega_{1}$ and, equivalently, the change of the covariance matrix from regime $i=1$ to regime $i=3$ as $\Delta \Omega_{31}=\Omega_{3}-\Omega_{1}$ equation (11) implies for $j=2,3$ :

\footnotetext{
${ }^{21}$ Additionally, $\alpha, \beta$ and $\gamma$ are assumed as stable across the covariance regimes, an assumption often invoked in the reaction function literature. We can test the validity of such an assumption (see below).
} 


$$
\Delta \Omega_{j 1}=\frac{1}{(1-\alpha \beta)^{2}}\left[\begin{array}{cc}
(\beta+\gamma)^{2} \Delta \sigma_{j 1, z}^{2}+\beta^{2} \Delta \sigma_{j 1, \eta}^{2} & (1+\alpha \gamma)(\beta+\gamma) \Delta \sigma_{i, z}^{2}+\beta \sigma_{i, \eta}^{2}+\alpha \sigma_{\varepsilon}^{2} \\
\cdot & (1+\alpha \gamma)^{2} \sigma_{i, z}^{2}+\sigma_{i, \eta}^{2}+\alpha^{2} \sigma_{\varepsilon}^{2}
\end{array}\right]
$$

where $\Delta \sigma_{j 1, z}^{2}=\sigma_{j, z}^{2}-\sigma_{1, z}^{2}$ and $\Delta \sigma_{j 1, \eta}^{2}=\sigma_{j, \eta}^{2}-\sigma_{1, \eta}^{2}$. Hence, $\Delta \Omega_{j 1, k l}$ in equations (9) and (10) is the element $k$ and $l$ in matrix $j=2,3$. In this fashion we are able to test the stability of $\beta$ to the selection of volatility regimes. ${ }^{22}$

Among the objections one might raise about the proposed specification is that it presumes the Fed reacts to stock returns, instead of 'excessive' speculation which the historical evidence suggests may have been of relatively greater concern to policy-makers. Indeed, a preoccupation of the Fed at the time focused on the possibility of a stock market bubble. Though this expression was not used in the 1920s, Wicker (2005) points out that reference to "boom psychology" amounts to essentially the same concept. Therefore, it may not have been stock returns per se that belong in the Fed's reaction function but, rather, the degree to which the stock market may have been over-valued. While space limitations prevent a discussion of the difficulties surrounding the measurement of stock market bubbles suffice it to say that several economists believe that a bubble existed in 1928-29. ${ }^{23}$ Among the simplest tests for detecting the presence of bubble like behavior is to ask whether stock prices behave like a random walk. If markets are efficient the (log) dividend-rice ratio should display unit root behavior. Santoni (1987) finds this to be the case while Bohl and Siklos (2004), relying on threshold unit root and cointegration tests, find asymmetry in the random walk like behaviour of the dividend-price ratio consistent with the structural slumps view of Phelps (1994), relying on data that also covers the 1920-1938 period. Alternatively, one could simply apply a Hodrick-Prescott filter to the log of stock prices to obtain a proxy for the extent to which the stock market was over or undervalued through time. All of these proxies were estimated and used to represent $s_{t}$ in equation (3).

\subsection{Structural VARs}

A more conventional approach consists in estimating the VAR (5), possibly adding other endogenous as well as exogenous control variables, but imposing some suitable identifying

\footnotetext{
${ }^{22}$ For further details on the solution of the identification problem see the appendix in Rigobon and Sack (2001) and Rigobon (2003).

${ }^{23}$ For example, Chandler (1970), Wigmore (1985) find in favour of the bubble hypothesis while Santoni (1987) and McGratan and Prescott (2003) reach the opposite conclusion.
} 
restrictions which yields a structural VAR (SVAR). Impulse responses and variance decompositions can then be examined to determine the size of the interest rate response to stock returns. Long-run restrictions are defined such that the accumulated impulse responses are set to zero. As the general procedures involved in estimating structural VARs are well-known, readers are referred elsewhere for the details (e.g., see Hamilton 1994).

A common assumption in the literature is that output and inflation do not react contemporaneously to monetary policy shocks. ${ }^{24}$ Bjørnland and Leitemo (2005) consider the additional restriction that monetary policy has no long-run impact on stock prices. This type of SVAR is estimated below for the available data.

It is important to point out that the set of long-run restrictions often resorted to in the literature does not identify $\beta$ using changes in the volatility of key macroeconomic aggregates, a feature of the data I argued above pre-occupied policy-makers throughout the sample considered. Nevertheless, results from SVARs should aid in illuminating the relationship between interest rates and stock returns and, in particular, the relationship between monetary policy shocks and stock returns.

\section{Empirical Estimates}

Tables 3 and 4 present estimates of $\beta$ in (3) relying on Rigobon's approach. The distribution of $\beta$ is evaluated via bootstrapping (see Rigobon 2003). The results in Table 4 are based on a VAR where deviations of stock prices from some fundamental value proxies $s_{t}$ in equation (3). Once again this is tantamount to assuming that the Fed had some target for stock market performance. ${ }^{25}$ As noted earlier, the technique used here requires that at least three volatility regimes be identified. While rolling standard deviations, GARCH $(1,1)$, and Markov switching approaches led to somewhat different dating of volatility regimes, the impact on the estimated value of $\beta$ is generally modest.

\footnotetext{
${ }^{24}$ Bagliano and Favero (1998) demonstrate that Rudebusch's (1998) critique of VARs does not suffer from the Lucas critique. Sims (1998) also dismisses Rudebusch (1998) as not supported by a more careful understanding of what VARs are meant to accomplish, namely estimate what could meaningfully be called a monetary policy shock. ${ }^{25}$ For the VARs I relied on the NBER's estimates of industrial production (series m16002a) available from www.nber.org. The output gap is then simply the HP filtered log level of the index series using a smoothing factor of 192,600. Since $\tilde{s}_{t}=\left(s_{t}-s_{t}^{H P}\right)$ is used, where $\tilde{s}_{t}$ is the H-P filtered log of stock prices, the implicit assumption is that the Fed targeted some trend level in stock returns. The conclusions were unaffected when we used the levels of the same endogenous variables.
} 
There is a statistically significant negative contemporaneous relationship between stock returns and interest rates when three volatility regimes are identified $(\hat{\beta}=-0.49)$. This result holds up even if we use the spread between the discount rate and the commercial paper rate, although with a p-value of 0.11 the estimate of $\beta$ is not, strictly speaking, statistically different at the conventional $10 \%$ level. It appears that a policy of monetary ease (i.e., a lower nominal interest rate) can contemporaneously explain rising stock returns. This suggests that monetary policy was indeed contributing to the eventual stock market 'bubble'. When four regimes are assumed, chosen according to the earlier historical narrative, then $\beta$ is no longer statistically significant. However, since the case with four regimes is over-identified, we can test whether the additional restriction can be rejected. When the dependent variable is the change in the interest rate, the null that $\Delta \hat{\beta}=0$ cannot be rejected, and the $\mathrm{p}$-values are such that the hypothesis of coefficient stability cannot be rejected. Therefore, estimates relying on three volatility regimes are correct. When the dependent variable is the interest rate spread there is a rejection of the null of constancy for the case where regime II (1929-31) is excluded. However, the coefficient remains negative $(\hat{\beta}=-1.30)$ and does not differ much from the all regimes estimate shown in line 1.

Table 4 considers additional tests of the robustness of the findings reported in Table 3. Stock returns are now proxied by the log change in the dividend-price ratio. When volatility regimes are chosen according to a $\operatorname{GARCH}(1,1)$ model (Table $4 \mathrm{~A})$, there is some evidence of parameter instability. While the estimate across all regimes remains negative but statistically insignificant, as reported in Table 3, exclusion of the period 1932-34 results in a positive relationship between the interest rate and the dividend-price ratio. This translates into a fall in stock prices (see section 4.1). Finally, when a Markov switching approach is used to estimate volatility regimes, the relationship between interest rates and the dividend-price ratio becomes statistically insignificant. However, as the null that $\Delta \hat{\beta}=0$ cannot be rejected in any of the cases considered, there is no reason to consider this number of volatility regimes. Hence, the results in Table 4A remain valid and consistent with the findings in Table 3.

It is also worthwhile asking whether the foregoing results are dependent on the identification assumptions. Bjørnland and Leitemo (2005) estimate a structural VAR (SVAR) that combines the short-run identification assumptions of Christiano, Eichenbaum and Evans 
(1999) together with the further restriction that monetary policy has no long-run effect on (real) stock returns. A five variable VAR that consists of the output gap, inflation, commodity price inflation, the interest rate (either in levels or in first differences), and stock returns, as the endogenous variables, was estimated. Other estimation details are provided in Table 5.

Figures $5 \mathrm{~A}$ and $5 \mathrm{~B}$ plot the impulse responses to a monetary policy (MP) shock using the identification assumptions of Bjørnland and Leitemo (2005). A positive MP shock, again following Christiano, Eichenbaum and Evans (1999), signals a tighter monetary policy. To conserve space, I omit the responses of commodity prices as well as the responses from to the other structural shocks in the system. These are available on request. The impulse responses differ as between the 1920-29 and 1931-38 samples. MP shocks are expansionary after 2 periods (months) prior to the stock market crash but the size of the response is economically small. In contrast, a tightening of monetary policy is contractionary for up to 9 periods after 1930. Clearly, the Fed did not tighten sufficiently prior to the stock market crash, and this conclusion is also compatible with the result from applying Rigobon's procedure. MP shocks are deflationary prior to the stock market crash while the same sized shock is mildly inflationary in the 1931-38 sample, at least for the first 2 periods. It is also interesting to note that a MP shock elicits a negative interest rate response after only 3 months. ${ }^{26}$ In contrast, the responses remain positive throughout the post 1929 stock market period (Figure 5B), a finding that is reminiscent of the results obtained for more recent U.S. data (e.g., Christiano, Eichenbaum, and Evans 1999). Finally, notice that MP contributes to rising stock prices, at least for the first 3 periods, while the response is largely negative in the 1931-38 sample. These results are also consistent with the results based on the Rigobon procedure.

Turning to the variance decompositions provided in Tables $5 \mathrm{~A}$ and $5 \mathrm{~B}$, we first find that in the 1931-38 sample (Table 5B), a MP shock explains output, inflation, the interest rate and stock returns in roughly equal proportions, at least at horizons of 5 months or longer. Moreover, the impact of a MP shock remains persistent over at least 10 periods. There are, however, two noticeable differences between the two samples. While MP shocks explain similar proportions of the variation in inflation and the interest rate in both samples, the variance decompositions of a MP shock on output and stock prices are much smaller in the pre 1929 stock market crash

\footnotetext{
${ }^{26}$ The fact that the interest rate variable enters in levels in the SVARs presented in Figures 5A and 5B makes no difference to the results. They are qualitatively the same results when the interest rate is differenced.
} 
period than in the second sub-sample considered. The general implication of these results is that MP explains a smaller portion of the variation of output and stock prices prior to 1929 than after this event. Therefore, there was greater policy activism after the Crash. Moreover, the results complement the ones obtained via the Rigobon approach and reveal a more activist Fed after the 1929 stock market crash.

There are clearly advantages and drawbacks to relying on SVARs to address the questions of interest in this paper (also, see Rubio-Ramírez, Sargent, and Watson 2007). First, none of the specified SVARs permit a direct role for the volatility in the macroeconomic time series of interest. Second, we are not able to examine sample or regime sensitivity of impulse responses and variance decompositions to the same extent as when Rigobon's procedure is used. Finally, it is difficult to know whether policy-makers would have been guided by the principle of the long run neutrality of monetary policy on stock returns, while the results that rely on changing volatility to identify the Fed's reactions to the stock market arguably seem closer to the reality of how policy was conducted during the time investigated in this study. Nevertheless, SVARs allow us to evaluate the impact of the various shocks - not only the MP shocks - on all the endogenous variables in the model unlike Rigobon's identification through heteroskedasticity approach. The results presented in Figure 5 and Table 5 support the findings in Tables 3 and 4, and even those presented in Tables 1 and 2 that rely on Taylor rule estimation.

\section{Conclusions}

This paper has examined the conduct of US monetary policy during the period 19201938, paying particular attention to the potential role of stock market developments in influencing interest rate determination, and relying on volatility in selected macroeconomic indicators to identify Fed interest rate setting behavior. I find that the Fed did indeed take into account stock market performance but that its reaction may have hastened the onset of the stock market crash of 1929. A negative contemporaneous correlation between stock prices and interest rates is a feature of the data prior to approximately 1929. Thereafter, the Fed reacted to rising stock prices by increasing interest rates. Therefore, monetary policy responses did indeed change during this watershed era in U.S. economic history. A plausible scenario is that the RieflerBurgess model led to erroneous policy decisions until the early 1930s. More importantly, volatility contributed to fostering disagreement among policy-makers over the proper course of action. A lack of cohesion in the decision-making process also exacerbated monetary policy's 
contribution to the severity of the Great Depression. The paper also illustrates how the use of real time data to conduct inferences about policy making can yield useful insights that can help explain the shift in the Fed's thinking after 1928. Unfortunately, data limitations prevent the use of real time data to estimate the contemporaneous impact of stock returns on the interest rate. This could be the subject of future research. Similarly, it would be interesting to speculate whether the Fed's behaviour would have been different had the Stabilization Bills, advocating a policy akin to what today would be called inflation targeting, been passed by Congress in the 1920s (see Meltzer 2003). This kind of counterfactual experiment is also left for future research. 
Table 1 Estimated Taylor Rules: Equation (1)

$$
i_{t}=i^{*}+\rho_{1} i_{t-1}+\rho_{2} \Delta i_{t-1}+\phi_{\pi} \pi_{t}+\phi_{\tilde{y}} \Delta \tilde{y}_{t}+\varepsilon_{t}
$$

\begin{tabular}{|c|c|c|c|c|c|c|c|}
\hline & (1) & (2) & (3) & (4) & (5) & (6) & (7) \\
\hline Coefficient $^{2}$ & $\begin{array}{l}1920.01 \\
1938.06\end{array}$ & $\begin{array}{l}1930.01 \\
1938.06\end{array}$ & $\begin{array}{l}1920.01 \\
1929.10\end{array}$ & $\begin{array}{l}1927.09 \\
\text { vintage }\end{array}$ & $\begin{array}{l}1929.09 \\
\text { vintage }\end{array}$ & $\begin{array}{l}\text { 1933.02 } \\
\text { vintage }^{1}\end{array}$ & $\begin{array}{l}1935.09 \\
\text { vintage }^{1}\end{array}$ \\
\hline$i^{*}$ & $\begin{array}{l}1.65 \\
(.248)\end{array}$ & $\begin{array}{l}1.26 \\
(.25)^{*}\end{array}$ & $\begin{array}{l}4.48 \\
(1.31)+\end{array}$ & $\begin{array}{l}-7.43 \\
(13.83)\end{array}$ & $3.78(4.48)$ & $\begin{array}{l}3.88 \\
(3.71)\end{array}$ & $4.17(2.50)^{*}$ \\
\hline$\phi_{\pi}$ & $\begin{array}{l}0.75 \\
(.77)\end{array}$ & $\begin{array}{l}-0.08 \\
(.25)\end{array}$ & $\begin{array}{l}0.87 \\
(1.02)\end{array}$ & $\begin{array}{l}10.25 \\
(13.78)\end{array}$ & $2.62(7.18)$ & $\begin{array}{l}2.24 \\
(5.25)\end{array}$ & $1.71(3.05)^{*}$ \\
\hline$\phi_{\Delta \tilde{y}}$ & $\begin{array}{l}-1.45 \\
(.43)+\end{array}$ & $\begin{array}{l}-1.87 \\
(.55)+\end{array}$ & $\begin{array}{l}-0.17 \\
(.84)\end{array}$ & $\begin{array}{l}0.91 \\
(0.51)^{*}\end{array}$ & $0.88(.47)^{*}$ & $\begin{array}{l}0.76 \\
(.50)\end{array}$ & $0.51(.41)$ \\
\hline$\rho_{1}$ & $\begin{array}{l}0.99 \\
(.01)+\end{array}$ & $\begin{array}{l}0.90 \\
(.03)+\end{array}$ & $\begin{array}{l}0.99 \\
(.01)+\end{array}$ & $\begin{array}{l}0.99 \\
(0.01)+\end{array}$ & $\begin{array}{l}.99 \\
(.01)+\end{array}$ & $\begin{array}{l}0.99 \\
(.01)+\end{array}$ & $0.99(.01)+$ \\
\hline$\rho_{2}$ & $\begin{array}{l}0.35 \\
(.06)+\end{array}$ & $\begin{array}{l}0.27 \\
(.09)+\end{array}$ & $\begin{array}{l}0.33 \\
(.10)\end{array}$ & $\begin{array}{l}0.24 \\
(.10)+\end{array}$ & $0.30(.09)+$ & $\begin{array}{l}0.30 \\
(.09)+\end{array}$ & $0.30(.09)+$ \\
\hline$\overline{\mathrm{ARCH}}(1)$ & $\begin{array}{l}1.54 \\
(.63)\end{array}$ & $\begin{array}{l}0.17 \\
(.68)\end{array}$ & $\begin{array}{l}0.42 \\
(.52)\end{array}$ & $\begin{array}{c}0.06 \\
(.81)\end{array}$ & $\begin{array}{l}.01 \\
(.91)\end{array}$ & $\begin{array}{l}.002 \\
(.99)\end{array}$ & $0.04(.89)$ \\
\hline $\mathrm{JB}$ & $\begin{array}{l}6130.78 \\
(.00)\end{array}$ & $\begin{array}{l}2124.42 \\
(.00)\end{array}$ & $\begin{array}{l}0.25 \\
(.88)\end{array}$ & $\begin{array}{c}0.29 \\
(.87)\end{array}$ & $\begin{array}{l}0.48 \\
(.79)\end{array}$ & $\begin{array}{l}0.54 \\
(.76)\end{array}$ & $0.31(.85)$ \\
\hline
\end{tabular}

Note: Estimates of (1) were generated using OLS (s.e. shown in parenthesis). ARCH(1) is the test for ARCH errors of order 1, and JB is the Jarque-Bera test of normality in the residuals (pvalues in parenthesis). See the text for variable definitions and symbols. Data are at the monthly frequency. ${ }^{1}$ Estimates are for a sample ending October $1929 ;{ }^{2}$ Steady-state coefficient estimates; for the constant the Null tested is whether $i^{*}$ is significantly different from zero, or whether $\phi_{\pi}$ is significantly different from 1 .

+ indicates coefficient is statistically significant, at least the $5 \%$ level (* at least at the $10 \%$ level). 
Table 2 Forward-Looking Taylor Rules: Equation (2)

$$
i_{t}=i^{*}+\rho_{1} i_{t-1}+\phi_{\pi} \pi_{t+3}+\phi_{\tilde{y}} \Delta \tilde{y}_{t+3}+\phi_{\tilde{y}} \tilde{y}_{t-1}+\varepsilon_{t}^{\prime}
$$

\begin{tabular}{|c|c|c|c|c|c|c|}
\hline & \multicolumn{3}{|c|}{$1920.01-1929.10$} & \multicolumn{3}{|c|}{$1930.01-1938.06$} \\
\hline & \multicolumn{6}{|c|}{ Instruments } \\
\hline Coefficient & SET1: standard & $\begin{array}{l}\text { SET2: } \\
\text { Standard+Money }\end{array}$ & $\begin{array}{l}\text { SET3: } \\
\text { Standard+Stock } \\
\text { returns }\end{array}$ & SET1: standard & $\begin{array}{l}\text { SET2 } \\
\text { Standard+Money }\end{array}$ & $\begin{array}{l}\text { SET3 } \\
\text { Standard+Stock } \\
\text { returns }\end{array}$ \\
\hline$i^{*}$ & $\begin{array}{l}5.58 \\
(2.03)+\end{array}$ & $\begin{array}{l}4.61 \\
(1.5)+\end{array}$ & $\begin{array}{l}4.38 \\
(.21)+\end{array}$ & $\begin{array}{l}0.12 \\
(.40)\end{array}$ & $\begin{array}{l}0.82 \\
(.15)\end{array}$ & $\begin{array}{l}0.91 \\
(.18)+\end{array}$ \\
\hline$\phi_{\pi}$ & $\begin{array}{l}0.08 \\
(.53)\end{array}$ & $\begin{array}{l}0.07 \\
(.10)\end{array}$ & $\begin{array}{l}0.03 \\
(.09)\end{array}$ & $\begin{array}{l}0.03 \\
(.05)\end{array}$ & $\begin{array}{l}.06 \\
(.03)\end{array}$ & $\begin{array}{l}-0.10 \\
(.02)\end{array}$ \\
\hline$\phi_{\Delta \tilde{y}}$ & $\begin{array}{l}0.03 \\
(1.54)\end{array}$ & $\begin{array}{l}-1.96 \\
(1.14)^{* * *}\end{array}$ & $\begin{array}{l}-3.19 \\
(1.24)+\end{array}$ & $\begin{array}{l}1.34 \\
(.46)+\end{array}$ & $\begin{array}{l}0.81 \\
(.30)+\end{array}$ & $\begin{array}{l}1.75 \\
(.35)+\end{array}$ \\
\hline$\rho_{1}$ & $\begin{array}{l}0.98 \\
(.04)+ \\
\end{array}$ & $\begin{array}{l}0.92 \\
(.03)+ \\
\end{array}$ & $\begin{array}{l}0.92 \\
(.04)+ \\
\end{array}$ & $\begin{array}{l}0.95 \\
(.01)+ \\
\end{array}$ & $\begin{array}{l}0.93 \\
(.01)+ \\
\end{array}$ & $\begin{array}{l}0.93 \\
(.02)+ \\
\end{array}$ \\
\hline$J B$ & $\begin{array}{l}0.90 \\
(.64) \\
\end{array}$ & $\begin{array}{l}5.18 \\
(.07) \\
\end{array}$ & $\begin{array}{l}3.49 \\
(.17) \\
\end{array}$ & $\begin{array}{l}2871.34 \\
(.00) \\
\end{array}$ & $\begin{array}{l}2986.01 \\
(.00) \\
\end{array}$ & $\begin{array}{l}2586.55 \\
(.00) \\
\end{array}$ \\
\hline$r_{1}^{2}$ & 0.48 & 0.57 & 0.55 & 0.14 & 0.12 & 0.11 \\
\hline$Q(1)$ & $\begin{array}{r}23.87 \\
(.00) \\
\end{array}$ & $\begin{array}{l}37.47 \\
(.00) \\
\end{array}$ & $\begin{array}{l}34.81 \\
(.00) \\
\end{array}$ & $\begin{array}{l}2.19 \\
(.14) \\
\end{array}$ & $\begin{array}{l}1.42 \\
(.23) \\
\end{array}$ & $\begin{array}{l}1.33 \\
(.25) \\
\end{array}$ \\
\hline$J$ & $\begin{array}{l}11.10 \\
(.52) \\
\end{array}$ & $\begin{array}{l}13.33 \\
(.77) \\
\end{array}$ & $\begin{array}{l}14.43 \\
(.70) \\
\end{array}$ & $\begin{array}{l}10.20 \\
(.60) \\
\end{array}$ & $\begin{array}{ll}12.24 \\
(.83) \\
\end{array}$ & $\begin{array}{l}12.24 \\
(.83) \\
\end{array}$ \\
\hline \multicolumn{7}{|c|}{ Tests for Instrument Relevance } \\
\hline \multicolumn{7}{|c|}{ Variable Partial $R^{2}$} \\
\hline$\pi$ & .45 & .45 & .47 & .44 & .52 & .72 \\
\hline$\Delta \tilde{y}_{t}$ & .16 & .21 & .22 & .30 & .43 & .38 \\
\hline \multicolumn{7}{|c|}{$F$-test } \\
\hline$\pi$ & 361.11 & 292.93 & 314.01 & 216.95 & 205.23 & 224.20 \\
\hline$\Delta \tilde{y}_{t}$ & 3.27 & 2.82 & 3.65 & 3.31 & 3.56 & 7.17 \\
\hline
\end{tabular}

Note: Estimates of steady state parameters based on (2) use GMM with robust s.e. shown in parenthesis. $r_{1}^{2}$ is the first order autocorrelation coefficient, $\mathrm{Q}$ is the Box-Ljung test for first order serial correlation, $\mathrm{J}$ is the test for the validity of over-identifying restrictions. Two tests for instrument relevance are the partial $\mathrm{R}^{2}$ due to Godfrey (1999) and the F-test (see Stock, Wright, and Yogo 2002) with bold values indicating rejection of the null of instrument irrelevance. An Fstatistic above 10 is considered sufficiently high to reject the null.

+ indicates statistically significant at at least the 5\% level. For coefficients, standard errors in parenthesis; for Q and J tests p-values are shown in parenthesis. SET1 consists of 6 lags of CPR and the right hand side endogenous variables in (2); SET2 is set $1+6$ lags of money growth (see the appendix for the definition and sources); SET3 consists of set 1+ 6 lags of the HP filtered $\mathrm{S} \& \mathrm{P}$ index. Equation (1) is estimated using OLS. All data are monthly. 
Table 3 Estimates of the Fed's Reaction to the Stock Market, 1920-1938

\begin{tabular}{|c|c|c|c|c|c|c|c|c|}
\hline & \multicolumn{4}{|c|}{ Dep. Var.: Change in CPR } & \multicolumn{4}{|c|}{ Dep. Var.: DR-CPR spread ${ }^{4}$} \\
\hline Regimes & $\hat{\beta}$ & $\Delta \hat{\beta}$ & $\boldsymbol{H}_{0}$ & p-value & $\hat{\beta}$ & $\Delta \hat{\beta}$ & $\boldsymbol{H}_{0}$ & p-value \\
\hline \multicolumn{9}{|c|}{ PARAMETER ESTIMATES FOR 3 REGIMES CASE } \\
\hline $\begin{array}{l}\text { All regimes }^{2} \\
3 \text { REGIMES }\end{array}$ & -0.49 & & $\beta=0$ & .055 & -1.07 & & $\beta=0$ & .11 \\
\hline \multicolumn{9}{|c|}{ TEST FOR PARAMETER STABILITY } \\
\hline $\begin{array}{l}\text { All regimes less I } \\
(1920-29)^{I}\end{array}$ & 0.28 & -.254 & $\Delta \hat{\beta}=0$ & .365 & -1.49 & -0.42 & $\Delta \hat{\beta}$ & .11 \\
\hline 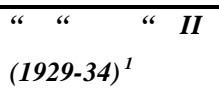 & -0.35 & -.324 & $\Delta \hat{\beta}=0$ & .125 & -1.30 & 2.97 & $\Delta \hat{\beta}$ & .07 \\
\hline \begin{tabular}{lll}
$“$ & \multicolumn{1}{l}{} \\
$(1934-38)^{I}$ &
\end{tabular} & 0.12 & -.094 & $\Delta \hat{\beta}=0$ & .425 & 1.70 & 2.99 & $\Delta \hat{\beta}$ & .24 \\
\hline \multicolumn{9}{|c|}{ PARAMETER ESTIMATES FOR 4 RETGIMES CASE } \\
\hline $\begin{array}{l}\text { Alternative } \\
\text { specification: } \\
4 \text { REGIMES } \\
\text { All regimes }^{1}\end{array}$ & .026 & & $\beta=0$ & .495 & 1.67 & & $\beta=0$ & .26 \\
\hline
\end{tabular}

1. Regimes: I = 1920.03 - 1929.01(low); II = 1929.02 - 1931.10 (high; Great Depression); III = 1931.11 - 1934.02(low); IV= 1934.03-1938.12 (high)

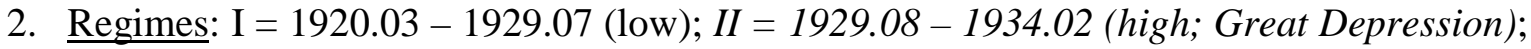
$\mathrm{III}=1934.03-1938.12$ (low)

Note: $\beta$ is the parameter measuring the Fed's reaction to the stock market. The model is given by equations (3) and (4). $\tilde{s}$ is defined as the H-P filtered log of stock prices. For the VAR, 2 lags in money growth and the output gap are included as exogenous variables in addition to four lags for the endogenous variables. The p-values for the null hypothesis shown are synthetic based on a bootstrapping procedure. See Rigobon (2003). Estimates are based on a GAUSS program adapted from Rigobon (2003). 
Table 4 Additional Estimates of the Fed's Reaction to the Stock Market, 1920-1938

A) Dating Volatility Regimes using a GARCH $(1,1)$ Model

\begin{tabular}{|l|l|l|l|l|}
\hline Regimes & $\hat{\beta}$ & $\Delta \hat{\beta}$ & $\boldsymbol{H}_{0}$ & $\boldsymbol{p}$-value \\
\hline All regimes & -0.29 & & $\beta=0$ & .390 \\
\hline \multicolumn{5}{|c|}{ TEST FOR PARAMETER STABILITY } \\
\hline $\begin{array}{l}\text { All regimes less I } \\
(\mathbf{1 9 2 9 - 3 0})^{I}\end{array}$ & 0.56 & .850 & $\Delta \hat{\beta}=0$ & .220 \\
\hline $\begin{array}{l}\text { " } \\
(\mathbf{1 9 3 2 - 2 4})^{I} \text { " II }\end{array}$ & 1.57 & 1.86 & $\Delta \hat{\beta}=0$ & .080 \\
\hline
\end{tabular}

B) Dating Volatility Regimes using a Markov Switching Model

\begin{tabular}{|c|c|c|c|c|}
\hline Regimes & $\overline{\hat{\beta}}$ & $\Delta \hat{\beta}$ & $\boldsymbol{H}_{0}$ & $p$-value \\
\hline All regimes ${ }^{2}$ & -0.54 & - & $\hat{\beta}=0$ & .380 \\
\hline \multicolumn{5}{|c|}{ TEST FOR PARAMETER STABILITY } \\
\hline $\begin{array}{l}\text { All regimes less I } \\
(1920)^{2}\end{array}$ & -0.47 & 0.07 & $\Delta \hat{\beta}=0$ & .370 \\
\hline $\begin{array}{l}\text { " } \\
(1929-30)^{2}\end{array}$ & -0.06 & 0.48 & $\Delta \hat{\beta}=0$ & .490 \\
\hline $\begin{array}{l}\text { “ } “ \\
(1931-34)^{2}\end{array}$ & -0.54 & 0.003 & $\Delta \hat{\beta}=0$ & .360 \\
\hline $\begin{array}{llll} & \text { “ } & \text { “ } & I V \\
(1937-38)^{2} & \end{array}$ & -0.46 & 0.08 & $\Delta \hat{\beta}=0$ & .410 \\
\hline
\end{tabular}

Notes: See Notes to Table 3. All data are monthly.

${ }^{1}$ Regimes: $I=1929.10$ - 1930.09 (high; Great Depression); II = 1932.01 - 1934.06 (high); all other months are low volatility regimes. Regimes are dated according to the variances from a $\operatorname{GARCH}(1,1)$ model fitted to the residuals for equation (3) in the VAR described in the text. $s$ is proxied by the log change of the dividend-price ratio.

${ }^{2} \mathrm{I}=1920.03$ - 1920.11 (high); II = $1929.04-1930.03$ (high; Great Depression); III = 1931.06 - 1934.06 (low); IV=1937.06-1938.01 (high); all other months are low volatility regimes. Regimes are dated according to a Markov switching model fitted to the log change in the dividend-price ratio. 
Table 5A Variance Decompositions from a Structural VAR: 1920-1929, Monthly

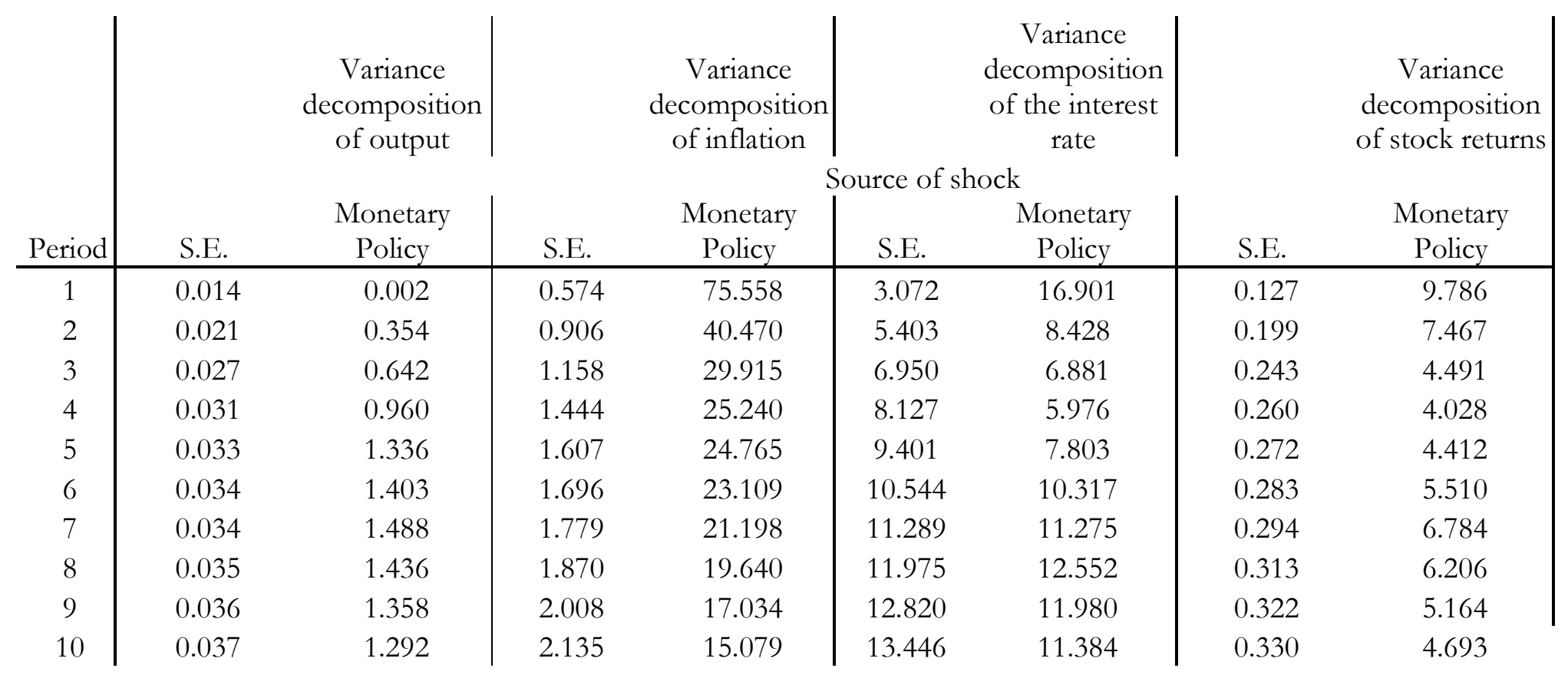

Note: A VAR consisting of the output gap, inflation, commodity price inflation, the nominal interest rate (NY commercial paper rate), and the HP filtered log of stock prices, in that order, with 12 lags is estimated. The restrictions imposed to achieve identification are described in the text. The sample is 1920:02-1929:10. The figures in the table are in percent. To conserve space only the impact of the monetary policy shock on the variables above are shown. Also not shown are impulse responses on commodity price inflation. 
Table 5B Variance Decompositions from a Structural VAR: 1930-1938, Monthly

\begin{tabular}{|c|c|c|c|c|c|c|c|c|}
\hline \multirow[b]{4}{*}{ Period } & \multirow[b]{4}{*}{ S.E. } & \multirow{4}{*}{$\begin{array}{c}\text { Variance } \\
\text { decomposition } \\
\text { of output } \\
\text { Monetary } \\
\text { Policy } \\
\end{array}$} & & \multirow{4}{*}{$\begin{array}{c}\text { Variance } \\
\text { decomposition } \\
\text { of inflation } \\
\text { Monetary } \\
\text { Policy } \\
\end{array}$} & \multirow{2}{*}{\multicolumn{2}{|c|}{$\begin{array}{c}\text { Variance } \\
\text { decomposition } \\
\text { of the interest } \\
\text { rate }\end{array}$}} & \multirow[b]{4}{*}{ S.E. } & \multirow{4}{*}{$\begin{array}{c}\text { Variance } \\
\text { decomposition } \\
\text { of stock returns } \\
\text { Monetary } \\
\text { Policy }\end{array}$} \\
\hline & & & \multirow[b]{3}{*}{ S.E. } & & & & & \\
\hline & & & & & \multirow{2}{*}{\multicolumn{2}{|c|}{ Monetary }} & & \\
\hline & & & & & & & & \\
\hline 1 & 0.020 & 13.237 & 0.564 & 18.425 & 2.845 & 38.467 & 0.162 & 0.503 \\
\hline 2 & 0.028 & 8.437 & 0.757 & 10.544 & 4.534 & 22.455 & 0.267 & 1.112 \\
\hline 3 & 0.039 & 6.642 & 0.881 & 11.075 & 5.889 & 13.309 & 0.375 & 4.453 \\
\hline 4 & 0.052 & 13.170 & 1.106 & 12.466 & 7.145 & 11.486 & 0.433 & 6.191 \\
\hline 5 & 0.059 & 12.054 & 1.324 & 15.182 & 8.797 & 11.207 & 0.468 & 7.978 \\
\hline 6 & 0.065 & 12.651 & 1.627 & 16.029 & 10.484 & 11.879 & 0.486 & 11.720 \\
\hline 7 & 0.071 & 14.618 & 1.974 & 17.956 & 11.996 & 11.798 & 0.504 & 13.147 \\
\hline 8 & 0.077 & 14.202 & 2.272 & 18.650 & 13.662 & 11.739 & 0.523 & 12.360 \\
\hline 9 & 0.081 & 13.280 & 2.556 & 17.865 & 15.543 & 12.622 & 0.540 & 11.637 \\
\hline 10 & 0.084 & 12.553 & 2.806 & 15.686 & 17.655 & 11.932 & 0.557 & 10.991 \\
\hline
\end{tabular}

Note: see note to Table 5A. The sample is 1931:06-1938:12 before lags. The same number of lags is the same as for the earlier sub-sample. 


\section{Figure 1 Comparing Volatility of Industrial Production and Stock Prices}

(A) Industrial Production
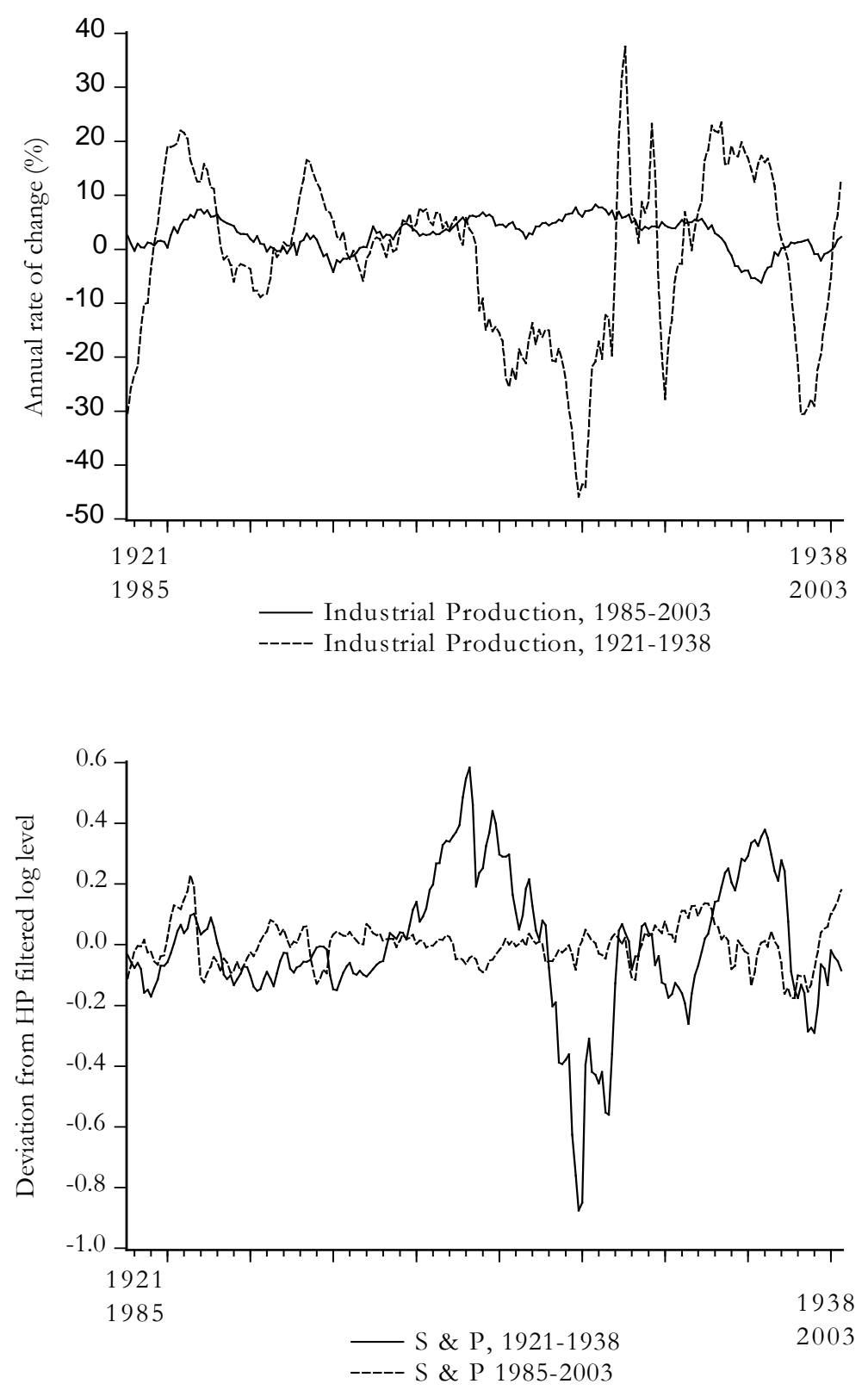

\section{(B) Stock Prices}

Note: Industrial production (1921-1938) is from FRED II (research.stlouis.fed.org/fred2) release G.17; data for 1985-2003 is from IFS (International Monetary Fund: Washington, D.C.). Annual rate of change in the index is evaluated as the fourth order log difference of the levels. S\&P data is from Global Financial Data and IFS (for 1985-2003). Log levels were HP filtered with smoothing parameter 14,400. 
Figure 2 Interest Rates and Stock Returns, 1920-1938

\section{(A) Short-term Interest Rates}

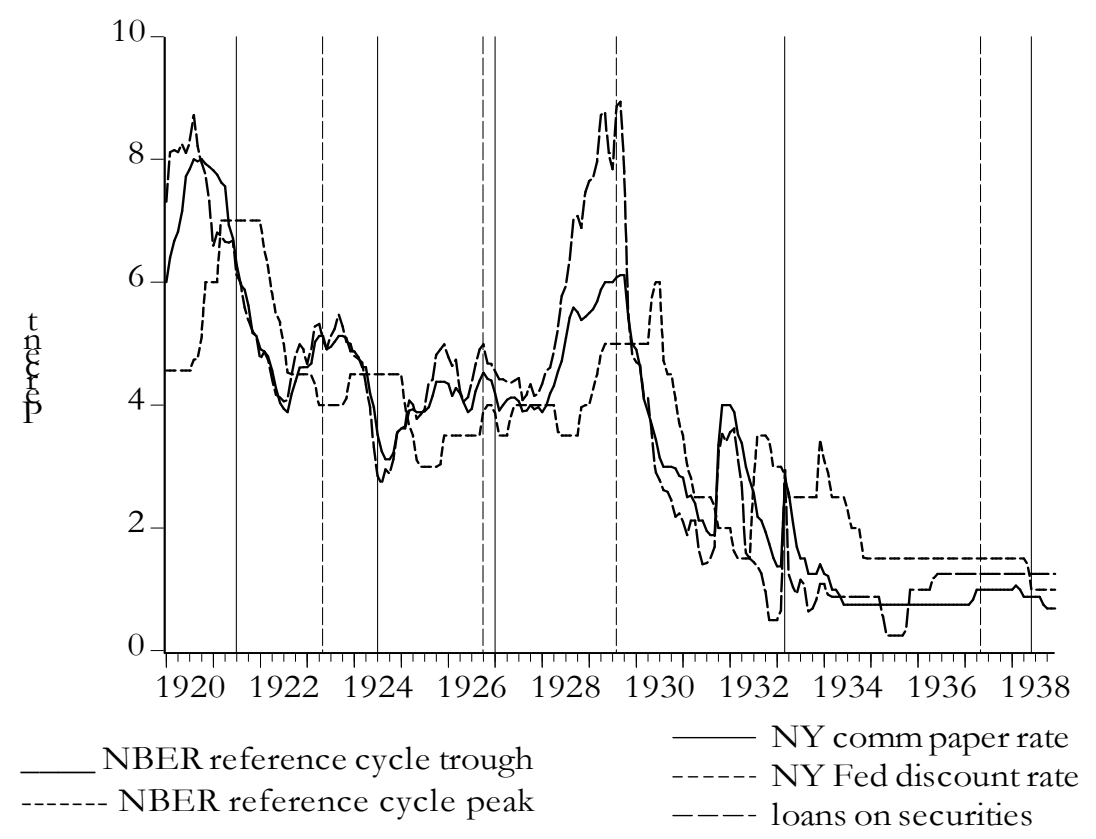

\section{(B) Stock Returns}

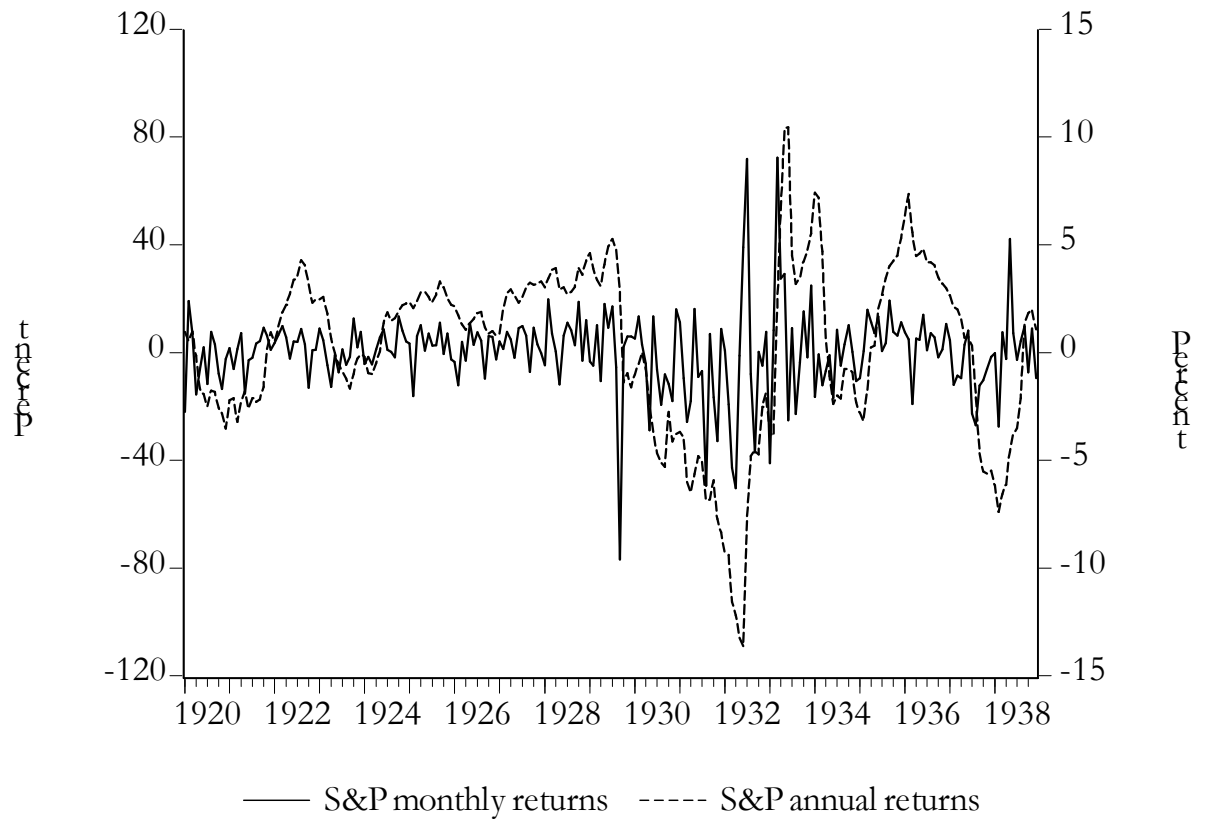

Note: See Figure 1. NBER reference chronology used is from www.nber.org. The solid line is the monthly return evaluated as the first log difference of the $\mathrm{S} \& \mathrm{P}$ index. The dashed line is the annual return evaluated as the fourth order difference in the log level of the S\&P index. Data are from Global Financial Data. 
Figure 3 Rolling Standard Deviations and Correlations: S\&P Index and N.Y. Commercial Paper Rate, Monthly
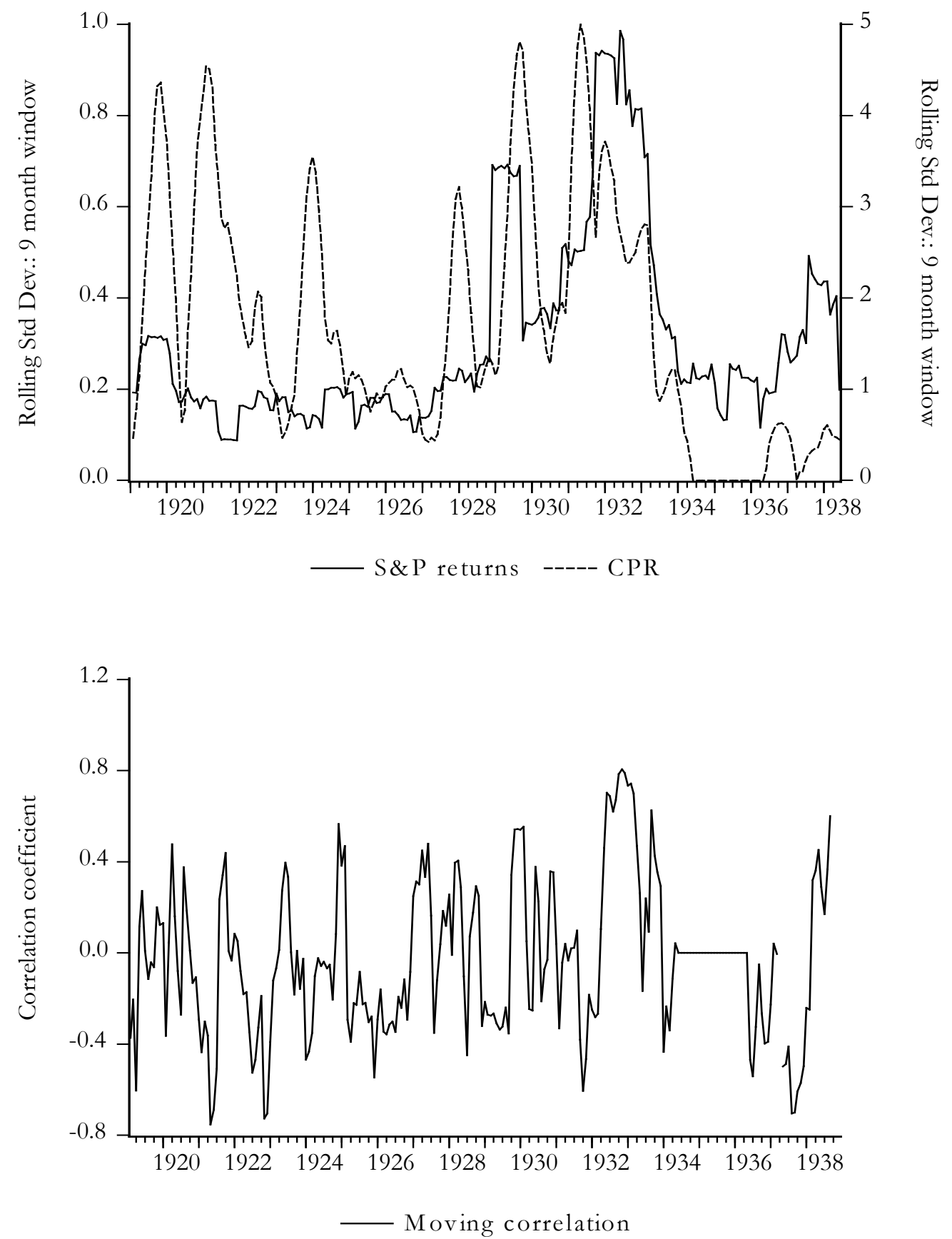

Note: See Figure 1. The top figure plots the rolling standard deviation of the series based on a 9 month window beginning with the 1919:02-1919.11 sample. The bottom plot shows the moving simple correlation coefficient between the S\&P and the commercial paper rate, again based on a 9 month rolling window. Data are from sources given in Figures 1 and 2. 


\section{Figure 4: Size of Revisions to Industrial Production By Vintage}
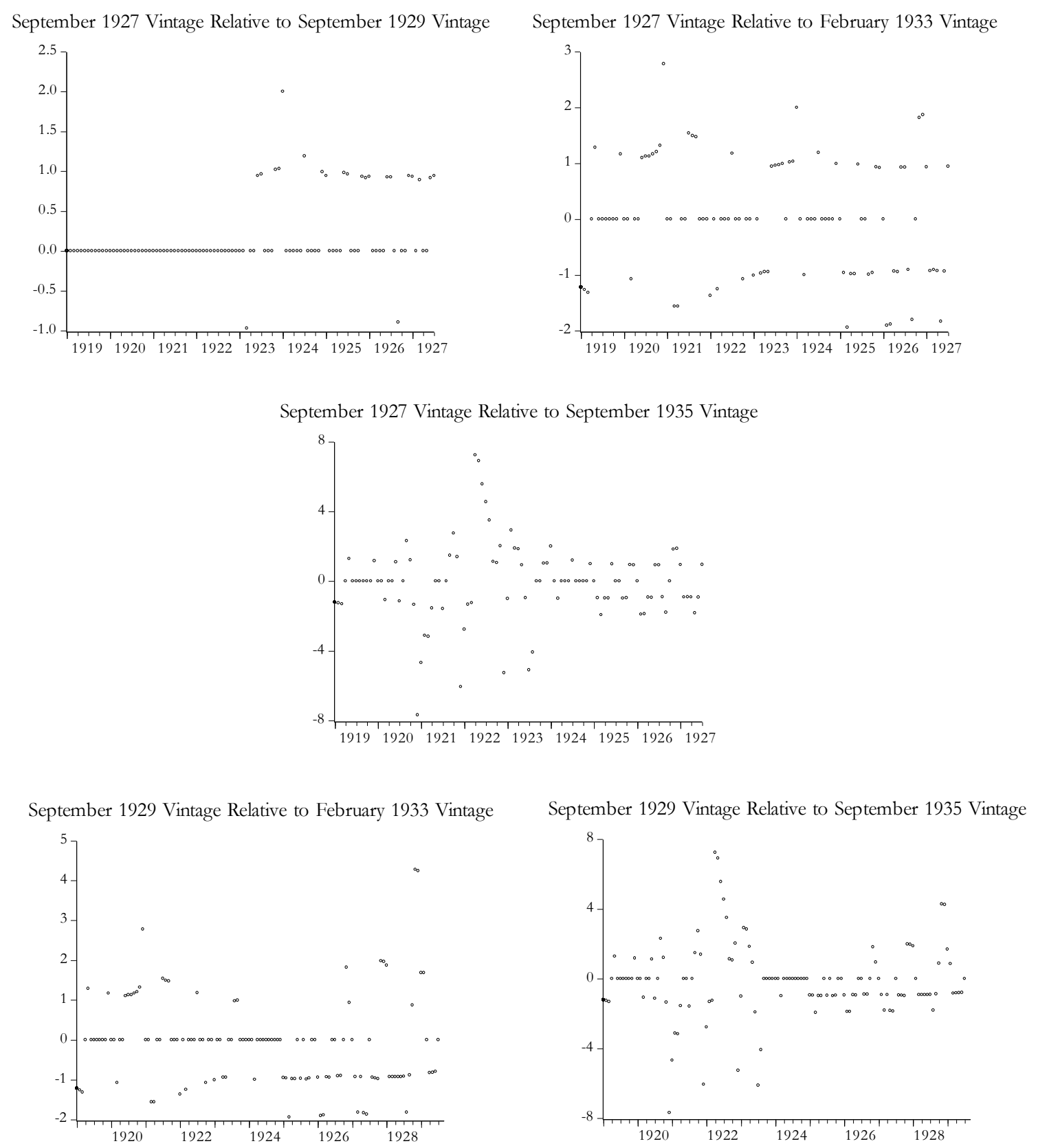

Note: The vertical axis is 100- (vintage (i) /vintage (j))*100, where vintage (i) is September 1927 or September 1929; vintage (j) is September 1919, February 1933, or September 1935. Source is given in the paper. Monthly data from 1919.01 to 1929.07 is plotted. 
Figure 5A Impulse Responses from a Structural VAR: 1920-29, Monthly

Response to Structural One S.D. Innovations

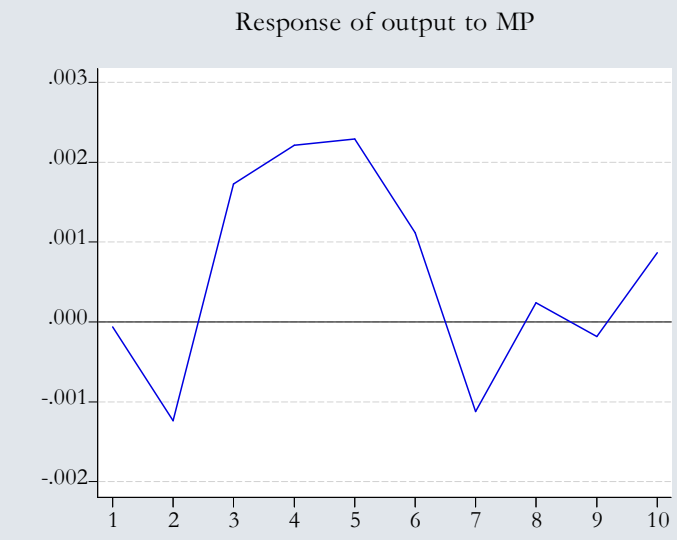

Response of inflation to MP

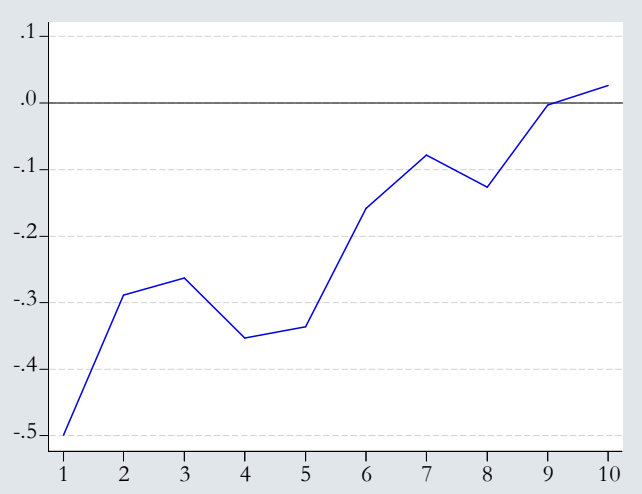

Response of the interest rate to MP

Response of stock returns to MP
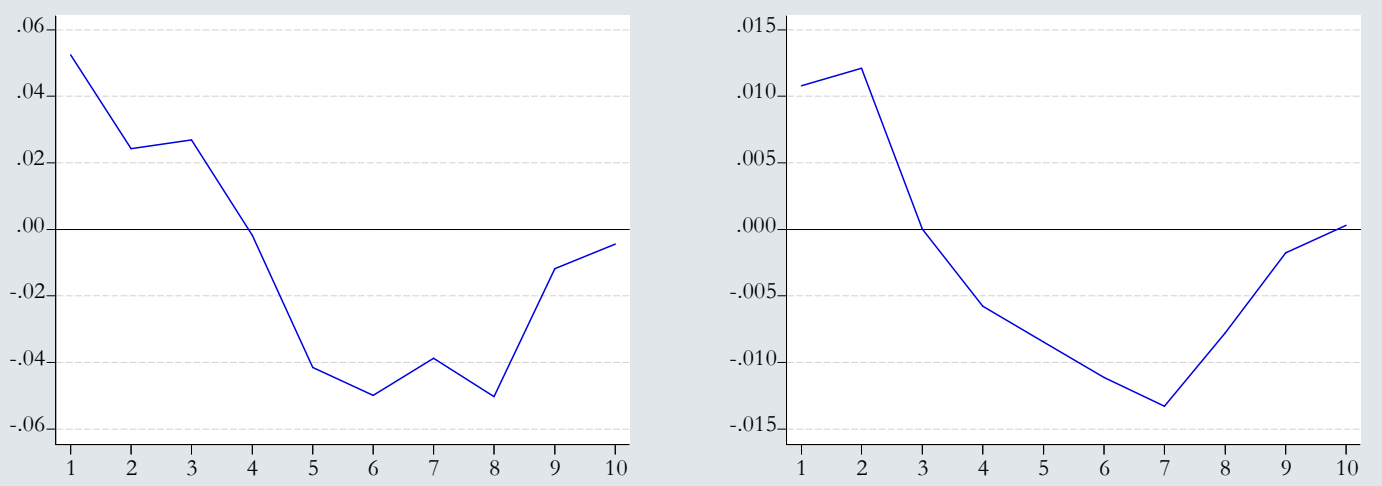

Note: Also see note to Table 5A for a description of the VAR. 
Figure 5B Impulse Responses from a Structural VAR: 1930-38, Monthly

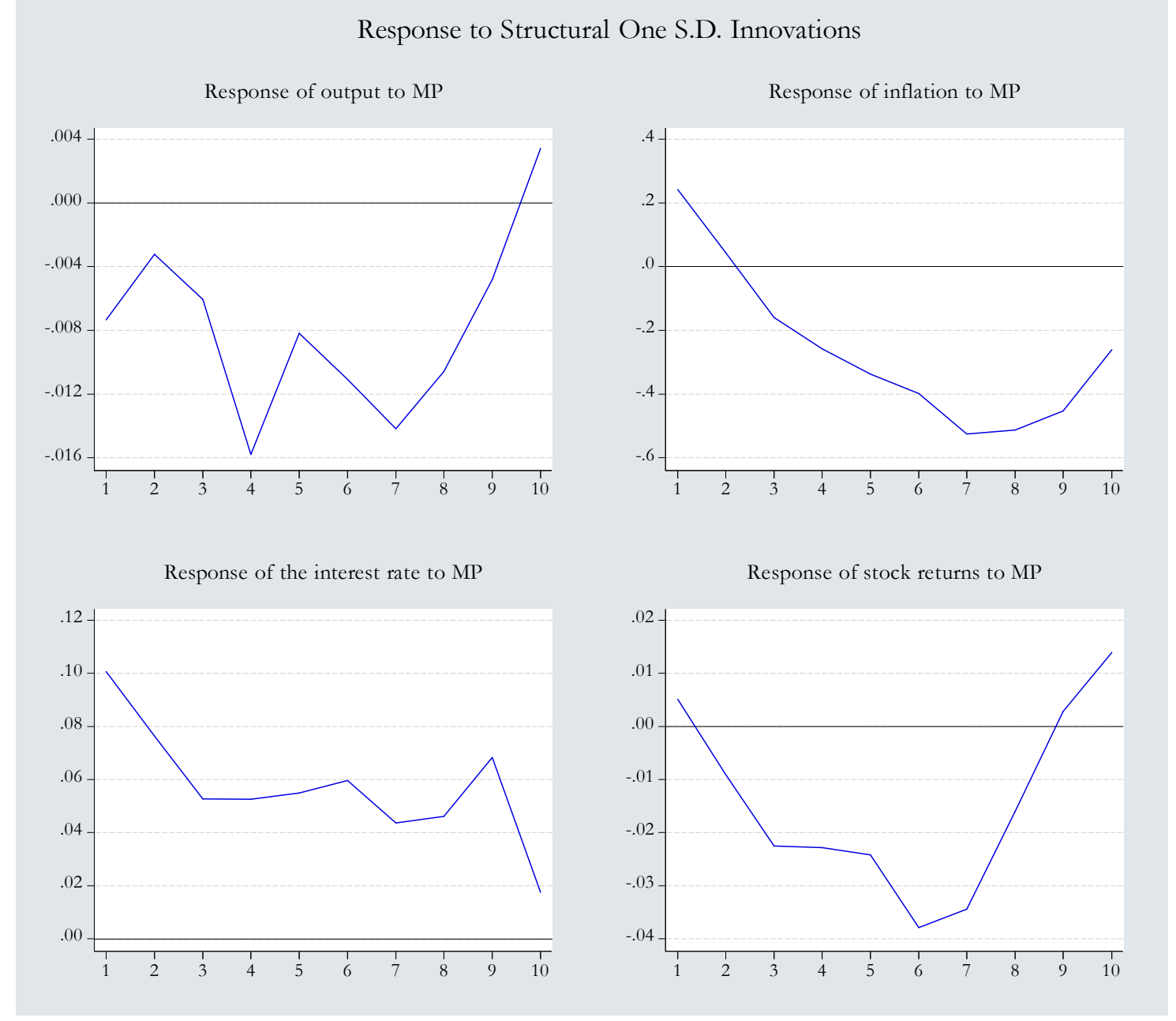

Note: See note to Figure 5A. 


\section{References}

Allen, F., and D. Gale (2000), “Bubbles and Crashes”, Economic Journal 110, 236-55.

Backus, D., and P. Kehoe (1992), "International Evidence on the Historical Properties of Business Cycles", American Economic Review 82 (September): 864-88.

Bagliano, C.F., and C. Favero (1998), "Measuring Monetary Policy in VAR Models: An Evaluation”, European Economic Review 42: 1069-1112.

Bernanke, B. (2002), “Deflation: Making Sure 'IT' Doesn't Happen Here”, remarks before the National Economists Club, Washington, D.C., 21 November, available at www.federalreserve.gov

Bernanke, B.S. (1983), "Nonmonetary Effects of he Financial Crisis in the Propagation of the Great Depression”, American Economic Review 73 (June): 257-76.

Bjørnland, H.C., and K. Leitemo (2005), "Identifying the Interdependence Between US Monetary Policy and the Stock market", working paper, University of Oslo, May,

Board of Governors (1943), Banking and Monetary Statistics, 1914-1941 (Washington, D.C.: Board of Governors of the Federal Reserve System).

Bordo, M.D., T. Helbling, and H. James (2007), "Swiss Exchange Rates in the 1930s: Was the Delay in Devaluation Too High a Price to Pay for Conservatism?", in The Swiss National Bank: 1907-2007 (Zürich: NZZ Libro).

Bohl, M., P. Siklos, and T. Werner (2007), "Do central banks react to the stock market? The case of the Bundesbank", Journal of Banking and Finance 31 (March): 719-33.

Bohl, M., and P. Siklos (2004), “"The Present Value of US Stock Prices Redux: An Alternative Testing Strategy and Some Evidence" Quarterly Review of Economics and Finance 44 (2004).

Bordo, M., and O. Jeanne (2004), "Boom-Busts in Asset Prices, Economic Instability, and Monetary Policy", in R.C.K. Burdekin and P.L. Siklos (Eds.), Deflation (Cambridge: Cambridge University Press).

Bordo, M., E. Choudhri, and S. Schwartz (2002), "Was Expansionary Monetary Policy Feasible During the Great Contraction? An Examination of the Gold Standard Constraint", Explorations in Economic History 39: 1-28.

Calomiris, C., and D. Wheelock (1998), "Was the Great Depression a Watershed for American Monetary Policy?" in The Defining The Great Depression and the American Economy in the Twentieth Century, M.D. Bordo, C. Golden, E.N. White, (Eds.), Chicago: University of Chicago Press), pp. 23-65. 
Chandler, L. (1970), America's Greatest Depression, 1929-1941 (New York: Harper and Row).

Christiano, L.J., M. Eichebaum, and C.L. Evans (1999), "Monetary Policy Shocks: What Have We Learned and To What End?", in J.B. Taylor and M. Woodford (Eds.), Handbook of Macroeconomics, vol 1A (Amsterdam: Elsevier), pp. 65-148.

Currie, J. (1934), "The Failure of Monetary Policy to Prevent the Great Depression of 1929-32", Journal of Political Economy 42 (April): 145-77.

Dominguez, K.M., R.C. Fair and M.D. Shapiro (1988), "Forecasting the Depression: Harvard Versus Yale", American Economic Review 78 (September): 595-610.

Eichengreen, B. (2004), “Viewpoint: Understanding the Great Depression”, Canadian Journal of Economics 37 (February): 1-27.

Eichengreen, B., and K. Mitchener (2004), "The Great Depression as a Credit Boom Gone Wrong", Research in Economic History, vol. 22, 183-237.

Eichengreen, B. (1992A), Golden Fetters: The Gold Standard and the Great Depression, 19191939 (New York: Oxford University Press).

Eichengreen, B. (1992B), "Designing a Central Bank for Europe: A Cautionary Tale from the Early Years of the Federal Reserve System", in J. von Hagen and C. Waller (Eds.), Regional Aspects of Monetary Policy in Europe (Dordrecht: Kluwer Academic Publishers).

Enders, W., and P.L. Siklos (2001), "Cointegration and Threshold Adjustment", Journal of Business and Economic Statistics 19 (April): 166-76.

Enders, W., and C.W.J. Granger (1998), "Unit Root Tests and Asymmetric Adjustment with an Example Using the Terms Structure of Interest Rates", Journal of Business and Economic Statistics 16 (July): 304-11.

Fackler, J.S., and R.E. Parker (2005), "Was Debt Deflation Operative During the Great Depression?" Economic Inquiry 43 (January): 67-78.

Field, A. (1993), "The Most Technologically Progressive Decade of the Twentieth Century", American Economic Review 93 (November): 1399-1413.

Fisher, I. (1930), The Theory of Interest (New York: Macmillan).

Fisher, I. (1933), “The Debt-Deflation Theory of Great Depressions", Econometrica 1 (October): 337-57.

Francis, N., and V. Ramey (2005), "Is the Technology Driven Real Business Cycle Hypothesis Dead? Shocks and Aggregate Fluctuations Revisited", Journal of Monetary Economics 52 (November): 1377-1399. 
Friedman, M., and A. Schwartz (1963), A Monetary History of the United States (Princeton: Princeton University Press).

Fuhrer, J.C., and H. Tootell (2004), "Eyes on the Prize: How Did the Fed Respond to the Stock Market?", Public Policy Discussion Paper 04-2, June, Federal Reserve Bank of Boston.

Giannoni, M., and M. Woodford (2003), How Forward-Looking is Optimal Monetary Policy?" Journal of Money, Credit and Banking 35 (December): 1425-1469.

Godfrey, L.G. (1999), "Instrument Relevance in Multivariate Linear Models", Review of Economics and Statistics 81 (3): 550-52.

Greenspan, A. (2005), "Reflection on Central Banking", Remarks at a Symposium Sponsored by the Federal Reserev Bank of Kansas City, Jackson Hole, Wyoming, 26 August 2005, available at www.federalreserve.gov.

Hall, A. (2005), Generalized Method of Moments (Oxford: Oxford University Press).

Hamilton, J. (1994), Time Series Analysis (Princeton: Princeton University Press).

Harris, S.E. 1933), Twenty Years of Federal Reserve Policy, vol. II: The Monetary Crisis (Cambridge, Mass.: Harvard University Press).

Hansen, B. (1997), "Inference in TAR Models", Studies in Nonlinear Dynamics and Econometrics 2 (April): 1-14.

Hetzel, R. (2007), The Monetary Policy of the Federal Reserve System: A History (Cambridge: Cambridge University Press).

Hoffman, D., and R. Rasche (1989), "The Demand for Money in the U.S. During the Great Depression: Estimates and Comparison with the Post War Experience", NBER working paper 3217, December.

Humphrey, T.M. (2001), "Monetary Policy Frameworks and Indicators for the Federal Reserve in the 1920s", Cato Journal (Fall).

Keynes, J.M. (1950), A Treatise on Money, vol. I: The Pure Theory of Money (London: Macmillan and Co. Ltd.).

McGrattan, E.R. and E.C. Prescott (2004), "The 1929 Stock Market: Irving Fisher Was Right”, International Economic Review 45 (November): 991-1009.

McGrattan, E.R. and E.C. Prescott (2003), "Testing for Stock Market Overvaluation/Undervaluation", in W.C. Hunter, G.R. Kaufman and M. Pomerleano (Eds.), 
Asset Price Bubbles: The Implications, Regulatory, and International Policies (Cambridge: The MIT Press), pp. 427-44.

Meltzer, A. (2003), A History of the Federal Reserve, Vol. I: 1913-1951 (Chicago: University of Chicago Press).

Mehrling, P. (2002), "Economists and the Fed: Beginnings", Journal of Economic Perspectives 16 (Autumn): 207-18.

Olney, M. (1999), "Avoiding Default: The Role of Credit in the Consumption Collapse of 1930", Quarterly Review of Economics 114(1): 319-35.

Orphanides, A. (2003), "Historical Monetary Policy Analysis and the Taylor Rule", Journal of Monetary Economics 50: 983-1022.

Orphanides, A. (2001), "Monetary Policy Rules Based on Real-Time Data", American Economic Review 91 (December): 964-85.

Perron, P. (1989), "The Great Crash, The Oil Price Shocks and the Unit Root Hypothesis", Econometrica 57 (November): 1361-1401.

Phelps, E. (1994), Structural Slumps: The Modern Equilibrium Theory of Unemployment, Interest, and Assets (Harvard: Harvard University Press).

Rappoport, P. and E.N. White (1994), "Was the Crash of 1929 Expected?", American Economic Review 84 (March): 271-81.

Reed, H. (1930), Federal Reserve Policy, 1921-30 (New York: McGraw-Hill).-

Rigobon, R. (2003), "Identification Through Heteroskedasticity", Review of Economics and Statistics 85 (November): 777-92.

Rigobon, R., and B. Sack (2003), "Measuring the Reaction of Monetary Policy to the Stock Market", Quarterly Journal of Economics 118: 639-69.

Rigobon, R., and B. Sack (2001), "Measuring the Reaction of Monetary Policy to the Stock Market”, NBER working paper 8350, July.

Romer, C. (1992), "What Ended the Great Depression?" Journal of Economic History 52 (December): 757-84.

Romer, C. (1990), "The Great Crash and the Onset of the Great Depression", Quarterly Journal of Economics 105 (August): 597-624.

Rubio-Ramírez, J.F., T.J. Sargent, and M.W. Watson (2007), “ABC's (and D's) of Understanding VARs”, American Economic Review 97 (June): 1021-26. 
Rudebusch, G. D. (1998), “Do Measures of Monetary Policy in a VAR Make Sense?”, International Economic Review 39 (November): 907-931.

Santoni, G.J. (1987), “The Great Bull Market: 1924-1929 and 1982-87: Speculative Bubble or Economic Fundamentals", Review of the Federal Reserve Bank of St. Louis 69(9): 16-30.

Sims, C. (1998), “Comment on Glenn Rudebusch's 'Do Measures of Monetary Policy in VAR Make Sense?", International Economic Review 39 (November): 933-941.

Stock, J.H., J.H. Wright, and M. Yogo (2002), “A Survey of Weak Instruments and Weak Identification in Generalized Method of Moments", Journal of Business and Economic Statistics 20 (October): 518-529.

Stock, J.H., and M.W. Watson (2003), "Forecasting Output and Inflation: The Role of Asset Prices", Journal of Economic Literature 41 (September): 788-829.

Thorbecke, W. (1997), “On Stock Market Returns and Monetary Policy”, Journal of Finance 52(2): 635-654.

Von Peter, G. (2005), "Debt-Deflation: Concepts and a Stylized Model”, BIS working paper 176, April.

Wheelock, D. (2000), "National Monetary Policy by Regional Design: The Evolving Role of the Federal Reserve Banks in Federal Reserve System Policy", in J. von Hagen and C. Waller (Eds.), Regional Aspects of Monetary Policy in Europe (Dordrecht: Kluwer Academic Publishers).

Wheelock, D. (1991), The Strategy and Consistency of Federal Reserve Monetary Policy, 19241933 (Cambridge: Cambridge University Press).

White, E.N. (2006), "Bubbles and Busts: the 1990s in the Mirror of the 1920s", NBER working paper 12138, March.

Wicker, E. (2005), "The Fed's Response to Two Alleged Asset Bubbles Contrasted: 1928-29 and 1995-2000”, working paper, Indiana University.

Wicker, E. (1966), Federal Reserve Monetary Policy, 1917-1933 (New York: Random House).

Wicker, E. (1965), “Federal Reserve Monetary Policy, 1922-53” A Reinterpretation”, Journal of Political Economy 73 (August): 325-43.

Wigmore, B.A. (1985), The Crash and Its Aftermath (Westport, CT: Greenwood Press).

Woodford, M. (2003), Interest and Prices (Princeton: Princeton University Press). 